\title{
Dos corpos, a terra: notas sobre a criatividade no trabalho de Rosa Tisoy $^{1}$
}

\author{
TATIANA LOTIERZO
}

Admiro o trabalho de Rosa Tisoy, artista inga do Valle de Sibundoy, no Alto Putumayo colombiano, por quem adquiri rapidamente uma imensa e afetuosa admiração. A performance Sara Indi (Milho de Sol) [imagens 1 e 2] contou com a participação de Sofía, a filha de Rosa, que naquela época contava sete anos e que, cuidadosamente, colava grãos de milho no corpo de sua mãe, formando diferentes desenhos. Outra série, Kanimi Alli Uñangapa (Sou Boa Semente) [imagens 3, 4, 5, 6, 7 e 8] é uma montagem fotográfica sobre um processo de gestação - no caso, a gestação da própria Rosa no interior de um grão de milho sobre a terra. Seu trabalho ainda inclui intervenções em que ela desenha motivos com sementes de milho sobre o chão ou montes de terra [imagens 9, 10,11] e instalações de vídeo e fotos que mostram esse tipo de desenho, entre outros artefatos - como por exemplo, bonecas feitas de palha de milho [imagem 12]. Em sua página na internet ${ }^{2}$, Rosa mantém os registros fotográficos dessas obras. Além das conversas que pude ter com ela durante minha pesquisa de campo, realizada no Valle de Sibundoy e em Bogotá ao longo de cerca de nove meses ${ }^{3}$, foi através dessas fotos e de outros materiais que ela me mostrou que pude acessar tais obras.

1 Tive a felicidade de receber comentários de Rosa Tisoy sobre este texto e agradeço muito pela troca sempre generosa que ela me propicia em nossas conversas e por ter autorizado o uso das fotos que acompanham esta publicação. O presente artigo é um exercício inicial e introduz parte de minha tese de Doutorado em andamento, intitulada Erosão num Pedaço de Papel. Além do SPG "Ecologia e Feminismos", pude apresentar uma versão em reunião interna do grupo de pesquisa "Estudos Interdisciplinares da Imagem", na Faculdade de Artes Visuais (FAV), da Universidade Federal de Goiás. Agradeço a Fabiana Maizza, Suzane Alencar e Rosana Horio Monteiro, assim como às pessoas que participaram desses encontros, pelos comentários, aportes e apoio - particularmente, a Luisa Elvira Belaunde, pelas sugestões e incentivo. Também agradeço aos dois pareceristas pelos comentários e sugestões valiosas.

2 Rosa Tisoy - Warmity: <http://rosatisoy.wixsite.com>. Última consulta: 09/07/2018.

3 Viajei à Colômbia em dois períodos distintos: de março a maio de 2016; e de abril a setembro de 2017. 
Rosa nasceu na vereda Vichoy, um dos cerca de 33 caminhos que se desprendem do pueblo ${ }^{4}$ de Manoy (Santiago), no Valle de Sibundoy, e se formou em Artes Plásticas pela Universidad del Cauca, em Popayán. Graduada, decidiu voltar a viver no Valle e lá mantém atualmente a Casa Ateliê Tisoy, localizada em Chaugpi Sibundoy (Colón), onde mora, expõe seu trabalho (sobretudo pinturas e desenhos) e se dedica a ensinar arte para crianças e jovens. Ela me contou que, ainda na graduação, entendeu que não queria usar grafite, caneta técnica ou outros materiais convencionais para desenhar; sentiu muita falta do Valle nessa época e, então, começou a sair da parte mais urbanizada de Popayán, buscando encontrar caminhos para se coectar a Vichoy, mesmo estando longe. Então passou a intervir nesses lugares, desenhando com folhas e cascas caídas das árvores, sementes e outros elementos que, depois, fotografava para mostrar aos professores. Nas palavras de Rosa:

Nas aulas de desenho, comecei a desenhar, mas não desenhava com lápis, eu era a única que não desenhava com lápis, então os demais gastavam em materiais, porque exigia o curso, eu comecei a desenhar em lugares afastados da cidade de Popayán, fincas, comecei a sentir mais falta do lugar de onde era, Vichoy, e de minha casa comecei a sentir falta, o lugar então me tocou, tinha que buscar os lugares mais naturais, mais saudáveis, e comecei a desenhar espirais, mas com folhas secas, com cascas de folhas, comecei como a fazer formas, mas que chegavam nesse mesmo momento, sem fazer esboços, nem nada, mas que era como permitir que a conexão com a natureza, que deixasse e que fluisse mais do que tudo, e comecei a desenhar e para mim eram desenhos pois, e a única coisa que eu fazia era fazer registros fotográficos e levar à universidade para mostrá-los aos professores. E foi algo bem bonito também como a formação e a aprendizagem que fazem parte do conhecimento e da própria formação para uma pessoa, para a vida, mas nunca me esquecendo das coisas e do lugar de onde sou, do lugar onde cresci e foi como ir a outro lugar, como comecei a valorizar mais o lugar, a casa, os percursos de quando era criança, comecei a fazer como uma memória a mais de minha infância e tudo começou, desde minha infância, a ser parte da criadora da arte, isso foi bem importante (ênfases minhas, tradução livre).

Se há no trecho uma percepção da importância de que os desenhos fluam a partir de uma "conexão com a natureza", como ela diz, ao conversar com a artista e por meio de outros encontros e atividades, fui percebendo que esse tipo de obra pode ser visto como outra forma de semear (tarpui, em inga) e lida com certas capacidades relacionadas ao cuidado da terra - não apenas em sua dimensão material, mas também existencial; mais do que isso, um desenho - e uma obra de arte - pode ser uma forma de perpetuar as coisas que vivem, pois envolve samai.

Samai é palavra que se traduz como alento: todos os corpos tem seu próprio samai. Bem dizendo, o mundo está composto por samai, tanto o dos corpos de um lugar, quanto o dos corpos que ali estiveram. Samai fica nas coisas, muito tempo depois que as vidas de seus donos se dissiparam ou que tais coisas deixaram de ser usadas. É também algo que se partilha de muitas maneiras, algo que flui ou emana por si só. Uma pessoa pode facilitar a circulação de samai. Soprar, por exemplo, é um ato de transmissão de samai que os taitas sinchi ou sinchi yachas (os sábios "duros" ou xamãs

4 Pueblo aqui tem o sentido de povoado. Manoy possui hoje uma população inferior a 4 mil habitantes, distribuída entre um pequeno núcleo urbano e cerca de 33 veredas. 
que curam as enfermidades mais graves) dominam; por isso, há diversos tipos de sopro, usados para muitas finalidades: para curar, sobretudo, mas também para fazer com que certas coisas aconteçam ou apareçam neste mundo. Os gestos, a respiração e a fala são atos que fazem circular samai e, assim, também são uma maneira de perpetuar a vida e transmitir conhecimento. A saudação diária entre os ingas, puangui, quer dizer "de mim”. É uma forma verbal carregada de samai, pois quando duas pessoas se cumprimentam, passam algo de si uma à outra, afetando-se. Para conhecer é preciso estar samai, ou seja, estar em condições de receber e partilhar samai com tudo o que esteja ao alcance de si. Efeito do samai, o conhecimento só acontece quando é partilhado no corpo dos diferentes seres que convivem num lugar.

Creio que, através daqueles desenhos, intervenções e performances, Rosa partilhava samai com diferentes tipos de plantas e outros seres - como acontece quando a terra é semeada - e também com seu público. Aprendi a vislumbrar, no trabalho de Rosa, uma forma de criatividade que envolve as mulheres inga numa espécie de fluxo de relações com a terra, as sementes e outros seres. Essas relações tornam-se aparentes através das chagras - áreas cultivadas - e do chumbe - faixa de tecido que conta histórias através de desenhos ${ }^{5}$-, entre outras atividades. Ao notá-lo, procurarei trazer elementos para pensar em que medida plantas e pessoas criam e cuidam umas das outras, algo que faz com que a vida possa se perpetuar no Valle de Sibundoy. Penso que uma chagra e um chumbe seriam expressões da criatividade das mulheres, assim como as mulheres - e tudo o que concebem (Strathern $1995)^{6}$, incluindo outras pessoas - seriam expressões da criatividade das plantas; mas também seria possível pensar que ambas se aproximam enquanto metáforas (Wagner, 1977 e 1986) da criativida$\mathrm{de}^{7}$. Criatividade é entendida aqui como algo que movimenta uma série de transformações contí-

5 Algumas outras observações são válidas: além dos ingas, o chumbe se encontra presente também entre os kamëntšá, os nasa/páez e os guambianos, entre outros povos na Colômbia, e remonta a tempos muito antigos, com origem, possivelmente, no Peru. A artista nasa Marisol Calambás também incorpora o chumbe em seu trabalho, como uma forma de transformação do tecido em pintura corporal, registrada na série fotográfica Nasa Yuwe (Língua de Gente), exposta na mostra Mira!, em 2013. Ao comentar sua experiência de pesquisa sobre chumbes nos Estados Unidos, quando teve acesso às coleções do Smithsonian Museum, Benjamín Jacanamijoy me disse que encontrou ali chumbes do período incaico e que eles continham os mesmos desenhos dos atuais. Ver Calambás 2014; Almeida e Mattos 2013 e, sobre os chumbes paez e guambianos, Baena 2004.

6 A antropóloga nota que conceber é um termo carregado de ressonâncias: no ocidente, concebem-se ideias, assim como crianças. Esse tipo de empréstimo do concreto ao abstrato dá "uma forma ou sentido de materialidade a um pensamento, ou intelectualizam uma experiência ou condição corporal" (Strathern 1995: 8, tradução livre). Já na Melanésia, as relações acontecem entre pessoas e, portanto, é o corpo (e o corpo estendido nas coisas), o lugar da concepção. Neste artigo, permanece o impasse em torno da palavra: a criatividade, afinal, pode fluir de ambas as maneiras, a depender de quem vê.

7 Wagner (1977) aproxima a noção de metáfora da de analogia; grosso modo, uma relação analógica pressupõe que cada termo possui múltiplas correspondências com outros termos, num dado contexto relacional. O antropólogo argumenta que, frente a um contexto de indiferenciação inicial entre termos (por exemplo, pai e mãe num contexto de solicitude relacional), cabe à ação humana estabelecer as diferenciações em meio ao fluxo analógico. Assim, a metáfora opera ao nível da coextensibilidade dos termos, no âmbito de uma convenção e fala sobre termos que representam uns aos outros, ao mesmo tempo em que expressam, denotam ou exemplificam um aspecto que possuem em comum. Mas a rigor, isso não partiria de nenhum tipo de forma dada a priori (por exemplo, de uma "natureza" entendida como dado): para que uma relação metafórica entre duas coisas se estabeleça, basta haver duas coisas, visto que qualquer coisa pode, potencialmente, representar qualquer outra coisa. Feita essa observação, reitero que neste artigo, ao dizer que são metáforas da criatividade (que se tornam metáforas num contexto relacional da criatividade) não pretendo reduzir a amplitude do que acontece nesses contextos. 
nuas, a fim de trazer coisas boas para este mundo, ou fazer com que coisas boas aconteçam. É, assim, algo que circula nos corpos e através deles ${ }^{8}$.

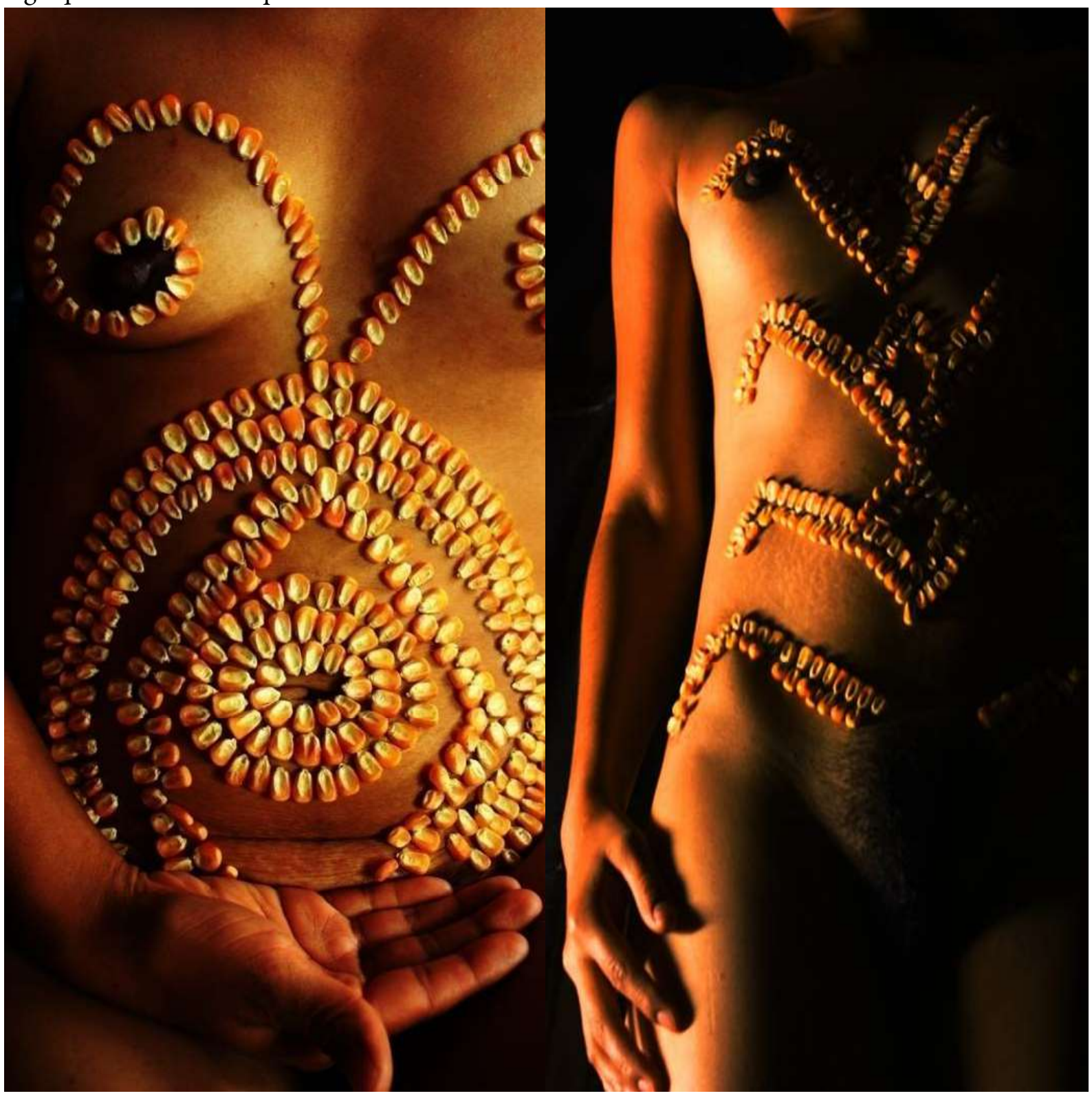

Imagem 1: Rosa Tisoy. Sara Indi [2013]. Fotografia (registro de performance). Acervo da artista.

Imagem 2: Rosa Tisoy. Sara Indi [2013]. Fotografia (registro de performance). Acervo da artista.

8 Os trabalhos de Luis Cayón (2013) e James Leach (2004) sugerem diálogos profícuos para este artigo. Junto aos Makuna, Luis Cayón (2013) encontrou diversas menções ao Pensamento como uma espécie de lugar onde estão guardados os componentes de tudo o que existe num mundo visível, ou atual. Pensamento se escreve com letra maiúscula por sua qualidade ressonante: não o pensamento como algo ligado à cognição individual, ou representações coletivas sujeitas a inesgotáveis interpretações, mas sim o centro da criatividade em si. Ele conta que cada corpo atual possui várias formas virtuais - componentes de sua vitalidade (üsi oka) que podem ser atualizados (criados, concebidos) em certas ocasiões. Há nisso encontros possíveis com o que pude aprender com meus amigos ingas. Para este artigo, importa situar algo que eles me ensinaram: que há muitos caminhos que permitem trazer novas coisas e seres para este mundo atual e tudo o que está aqui incorporado possui muitas possibilidades de existência virtual. Já James Leach (2004) chama a atenção para o fato de que na Rai Coast (Papua Nova Guiné), a criatividade não é fruto do intelecto individual ou da concepção de novas ideias, mas sim de combinações de pessoas: criatividade flui entre gerações de uma família. Guardadas as particularidades de cada contexto, também em meu campo fui percebendo a criatividade como um fluxo que produz tudo o que existe numa forma particular e que passa pelas relações entre pessoas e corpos. 
Nestas e nas próximas páginas, compartilho uma parte pequena das aprendizagens recebidas de uma série de pessoas que generosamente me acolheram em Bogotá e no Valle de Sibundoy. Destaco, entre muitas, a própria Rosa Tisoy - a quem agradeço imensamente pela leitura e os comentários a este artigo, bem como pelo incentivo que me deu para que o colocasse em circulação -; mamita Mercedes Tisoy de Jacanamijoy - grande yacha (sabedora) com quem tive o enorme privilégio de conviver em Manoy -; e Benjamín Jacanamijoy - amigo, artista por quem tenho grande admiração e autor das principais referências escritas sobre o chumbe inga, que tanto me ensinou sobre o pensar bonito, "a arte de contar a própria história" e muitos outros assuntos, estimulando-me a escrever e me ajudando a aperfeiçoar meus textos em diferentes ocasiões. Deixo a todos meus profundos e reiterados agradecimentos 9 .

Antes de começar, gostaria de dizer que este texto se publica aqui sem maiores mudanças editoriais e, portanto, mantém o formato do paper apresentado no SPG Ecologia e Feminismo, durante a Anpocs. Ele é, portanto, apenas uma amostra da maneira com que tenho enlaçado algumas dimensões daquilo que pude vislumbrar e escutar em campo, à qual incorporei sugestões valiosas dos pareceristas. Atesto aqui que foi sobretudo graças às conversas que tive com Benjamín que o texto adquiriu o formato que aqui se apresenta ${ }^{10}$. Ainda assim, os equívocos que ele possa conter são de minha total responsabilidade e, por isso, peço desculpas antecipadas.

9 Um dos pareceres recebidos para este artigo recomendava situar melhor a família Jacanamijoy Tisoy, supondo certas relações de parentesco entre Rosa e Benjamín e tomando-as como determinantes, visto que alguns de seus membros se destacam hoje como artistas. A família Jacanamijoy Tisoy, com a qual pude conviver mais proximamente (fiquei hospedada na casa de mamita Mercedes, em Manoy), é a família de Carlos Jacanamijoy - um dos principais artistas colombianos da atualidade -; de Benjamín; e de Néstor Jacanamijoy, irmãos (uajke), filhos de taita Antonio Jacanamijoy e de mamita Mercedes; e de Kindi Llajtu, sobrinho dos três, filho de Teresa Jacanamijoy - irmã (pane) de Carlos, Benjamín e Néstor. Os quatro tem formação superior em carreiras ligadas às artes (artes plásticas e Benjamín, design gráfico). Outros irmãos e irmãs destes três artistas são: Conchita, María, Antonio Segundo, taita Florentino, Rosa (Jacanamijoy Tisoy), taita Isodoro, Marlene e Matilde. Diferentemente do que pontua o parecer, Rosa Tisoy é filha do taita Benjamín Tisoy, primo de mamita Mercedes, e nunca conviveu em proximidade com os Jacanamijoy Tisoy, embora todos se conheçam. O mesmo parecer também sugere que, pelo fato de haver artistas ingas destacados e de alguns serem membros da mesma família, seria possível identificar uma espécie de movimento, ou mesmo "escola" artística, que poderia ficar mais evidente através de uma apreciação combinada das trajetórias de todos. Embora Carlos e Benjamín sejam de fato fontes de inspiração para os demais, não me sinto preparada para dar esse passo a partir daquilo que vislumbrei em campo, preferindo compartilhar algo que aprendi com esses artistas e outras pessoas (que não costumamos definir como "artistas"): o que eles me mostraram foi a importância do suma ruray ou bonito fazer, em conjunto com o suma yuyay, na perpetuação da vida como um todo, entendida como suma kaugsay - e não como parte de uma excepcionalidade artística identificada por eles como um movimento. Por isso, escolhi para o artigo um recorte que dá ênfase à noção de criatividade - algo que flui em diferentes atividades que se guiam pelo suma ruray, perpetuando a vida - e, particularmente, ao trabalho de Rosa. Reconhecendo a complexidade desse universo, também optei por não ampliar demais meu escopo através de aproximações entre Rosa e outros artistas indígenas de povos diferentes. Valorizo, entretanto, a aproximação que tem sido muito bem feita pelos(as) autores(as) que vêm produzindo reflexões em torno da exposição ¡Mira! (2012), por exemplo, ou que tem se dedicado há mais tempo a acompanhar essas tendências junto a diferentes povos (ver Almeida 2014; Almeida e Matos 2013; Belaunde 2016; Bendayán e Villar 2013; Cortés Garzón 2015; Mattos e Belaunde 2014). Esses trabalhos levantam questões interessantes como, por exemplo, aquela que diz respeito ao tipo de relação que os xamanismos e/ou o vasto conhecimento indígena sobre plantas poderia ter com as artes visuais (cf. p. ex. Belaunde 2016). Embora ela não esteja propriamente desenvolvida neste artigo (de fôlego limitado), não deixa de constar de minha tese de doutorado. Com isto, quero dizer que seria realmente fascinante pensar nas relações que tem crescido através dos encontros desses artistas, mas que isso exigiria, entretanto, outros caminhos de pesquisa para ser feito da maneira adequada.

10 Algo que comento em maior detalhe em minha tese de doutorado, em andamento. 

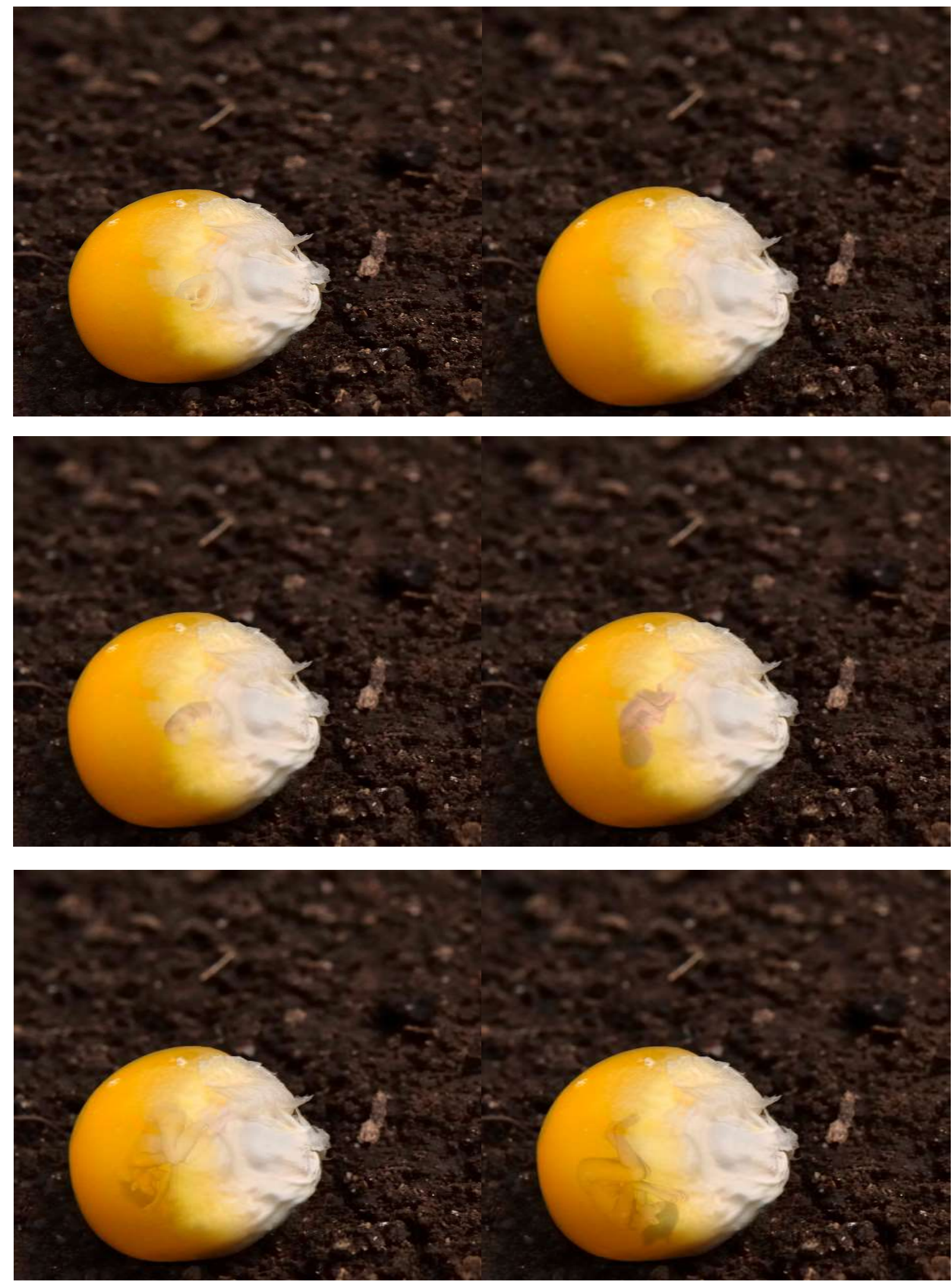

Imagens 3, 4, 5, 6, 7 e 8: Rosa Tisoy Kanimi Alli Uñangapa [2013]. Série de montagens fotográficas [fragmentos]. Acervo pessoal da artista 


\section{Chagra Suyu}

O Valle de Sibundoy localiza-se no Alto Putumayo colombiano, entre a Amazônia e a cordilheira dos Andes e comporta os pueblos indígenas de Manoy (Santiago), Uaira (San Andrés), Chaugpi Sibundoy (Colón), Sibundoy e Uaira Sacha (San Francisco).

O visitante que chega a esse lugar é surpreendido pela enorme quantidade de áreas cultivadas, as chamadas chagras. Não apenas os ingas, mas também os kamëntšá - o outro povo que habita essa região tem suas chagras, chamadas jajañ. E creio que não seria exagerado dizer que todas as casas inga possuem pelo menos uma chagra e, assim, essas roças podem ser vistas nas encostas das montanhas, nas veredas e mesmo nos canteiros que compõem a paisagem urbana em Manoy e Uaira (pueblos majoritariamente ingas), Sibundoy (majoritariamentekamsá) e Chaugpi Sibundoy e Uaira Sacha, cuja maioria da população é misturada e branca ${ }^{11}$.

Uma chagra é um tipo de roça que reúne uma grande variedade de plantas comestíveis e/ou medicinais: árvores, arbustos, plantas rasteiras e raízes. A maior parte das atividades importantes para a vida no Valle acontece na chagra e a partir dela. O plantio e o cuidado das plantas, a colheita, a extração da lenha que acende a tulpa (fogão de pedra) e as fogueiras, a alimentação dos animais e o preparo dos alimentos e dos remédios que são consumidos pelas pessoas que compartilham do espaço da casa demandam dedicação diária e permanente à terra cultivada.

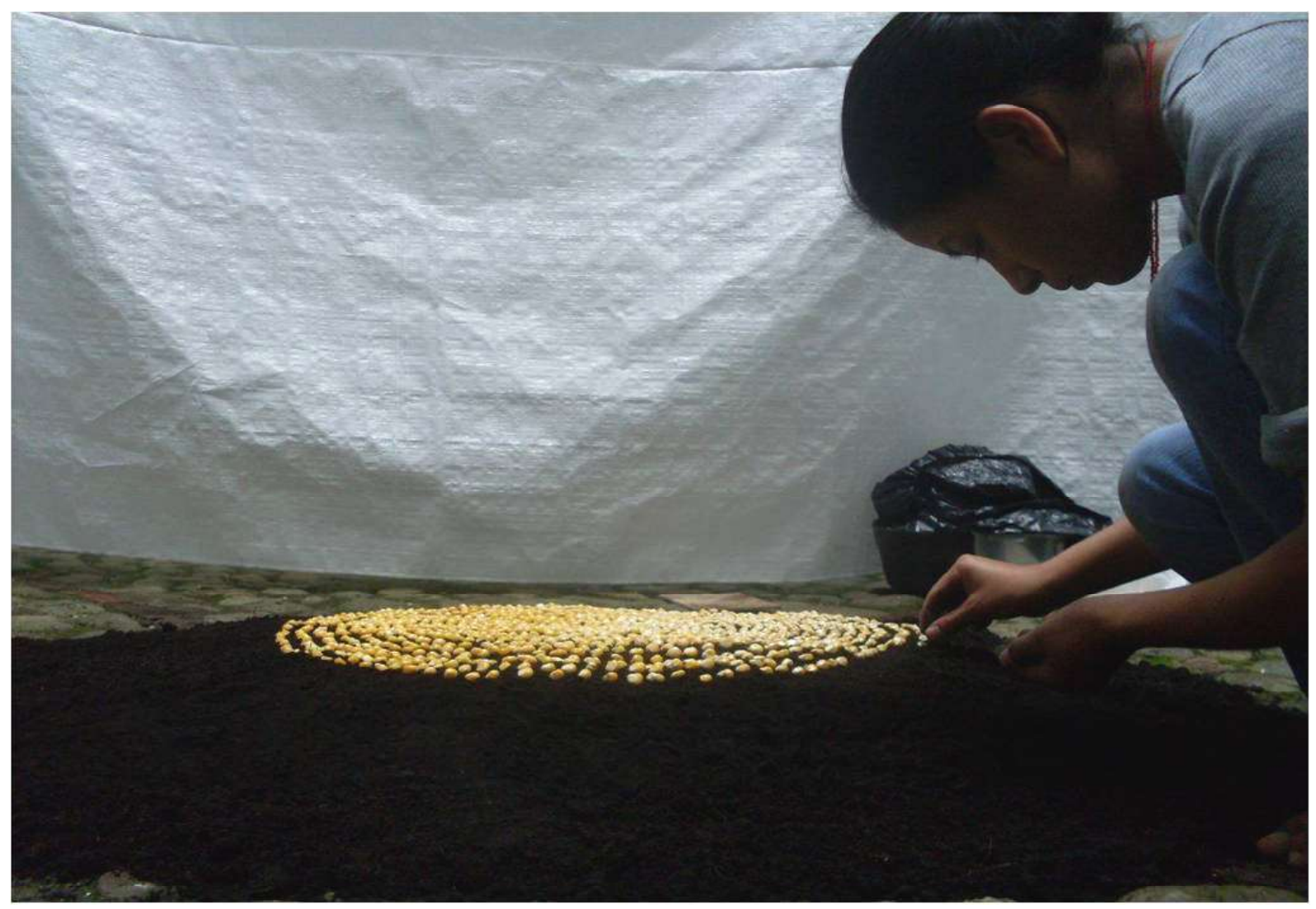

Imagem 9: Rosa Tisoy. Sem título [s.d.]. Fotografia (registro de performance). Acervo pessoal da artista

11 O Valle de Sibundoy contém alguns resguardos indígenas, quais sejam: Resguardos Kamëntsa, Valle de Sibundoy e Nukanchipa, ambos de população inga-kamëntšá; Sibundoy Parte Alta, kamëntšá; e Santiago, Samanoy, San Andrés, Inga, Alto San Pedro e (apesar do nome) Kamëntsa-Inga, ingas. Ver Corpoamazonia 2010. 
À primeira vista, a chagra inga se assemelha a uma pequena floresta, em que as diferentes espécies vão crescendo juntas, umas fazendo sombra e companhia às outras. Não há, aparentemente, intenção de desenhar ou projetar uma chagra em um formato específico ${ }^{12}$ - e em campo, não ouvi ninguém dizer que houvesse. As plantas que compõem esses espaços tem muita força e, por isso, nenhuma delas deve ser arrancada sem os devidos cuidados; por essa mesma razão, é preciso pisar cautelosamente ao entrar na chagra. Uma espécie esmagada pode "deixar o ar pesado”, como se adverte cotidianamente, afetando a saúde de todos os seres que compartilham desse espaço. Uma chagra costuma ser cuidada por uma mulher, embora essa não seja uma atividade exclusiva das mulheres; há homens que trabalham nas chagras e, como se sabe, os taitas (xamãs) possuem suas próprias chagras de plantas de poder, que mantêm separadas das demais, em lugares que só eles podem acessar.

As chagras são consideradas Lugares de Vida e Pensamento ${ }^{13}$ e por isso se diz Chagra Suyu, ou Lugar de Chagra: um lugar onde flui o bonito pensar (suma yuyay) e onde se perpetuar a existência através do cuidado das relações entre muitos seres que o habitam. No Chagra Suyu, a vida é concebida e o crescimento acontece. É um lugar que faz corpos plenos; assim, é também um lugar de criatividade. Os tipos de chagras existentes são a chagra uasi (chagra de casa), a atun chagra (grande chagra) e a yachajpa chagra (chagra do sabedor). A primeira é um tipo de roça doméstica, de onde saem diversos cultivos, como uma imensa variedade de frutas, batatas, mandioquinha, inhame, cuna ${ }^{14}$, guasimba ${ }^{15}$, feijões, pimenta e, sobretudo, milho, assim como ervas aromáticas, por exemplo, melissa, hortelã, erva doce e erva cidreira ${ }^{16}$. Ela fica sob os cuidados das mulheres.

Na segunda, também há cultivos como o do milho, o dos feijões, o das abóboras, batatas e mandioquinhas. Esta é uma área cultivada através de mingas, divichidos e conchavos - três modalidades de trabalho coletivo distintas: minga é um encontro de gente disposta a trabalhar nas chagras de alguém, sem remuneração; é um trabalho festivo, em que o dono da chagra oferece chicha (fermentado de milho) e comida a quem trabalha; divichido é trabalho na chagra de uma pessoa, que depois o retribui,

12 Como fariam, por exemplo, os Panará e Kayapó com seus cultivos circulares concêntricos. Cf. Heelas 1979; Hecht e Posey 1989; Posey e Plenderleith 2002; Ewart 2000, 2003 e 2005. Sobre as áreas cultivadas e as relações com plantas no mundo ameríndio, cf. Hugh-Jones 1979; Descola 1986; Rival 1993, 1998 e 2001; Santos-Granero 2011; e Oliveira 2012, entre outros.

13 Nas palavras de Benjamín Jacanamijoy (2001: 191), um lugar de vida - kaugsay suyu - "é um lugar onde cada um de nós convivemos com o outro, seja esse um ser humano, animal, vegetal ou mineral. É o espaço onde todos os seres cumprimos uma determinada função ou tarefa, com a perspectiva de construir uma convivência harmônica"; "para os ingas, o território constitui um lugar de convivência e de intercâmbio de conhecimentos, nesse sentido existem palavras que recolhem o significado que tem para nós o mundo como um único grande território subdividido por sua vez em uma considerável quantidade de lugares de vida e pensamento". Benjamín também me disse que "cada lugar forma um espaço [chipe], onde através do pensamento e da palavra se intercambiam conhecimentos". No Tulpa Suyu - Lugar da Tulpa, fogão de pedras - alguém conhece sua própria história; no Yagé Suyu - Lugar de Yagé -, recebem-se conhecimentos dessa planta; o Chagra Suyu - Lugar de Chagra - é "para agradecer as bondades da terra" - Alpa Mama, a Mãe Terra. Chipe, espaço, é a possibilidade sempre aberta de transformar um lugar; e como um caminho, pode ampliá-lo ou destruí-lo.

14 Tubérculo da família das Araceae, segundo os botânicos ocidentais; classificação não encontrada.

15 Tigridia pavonia, para os botânicos ocidentais.

16 Sobre o conhecimento médico das plantas entre as mulheres ingas, ver Giraldo-Tafur 2000. Outros trabalhos que mencionam as plantas e/ou a etnobotânica do Valle de Sibundoy - a maioria, focada no xamanismo inga e kamëntšá - são: Bristol 1965; Seijas 1969; García-Barriga 1974; Tisoy T. 1983; Chávez 1989; e Muñoz 1999. 
trabalhando nas chagras de quem esteve ali - assim, faz com que as pessoas circulem entre as chagras umas das outras. Conchavo, por sua vez, é um tipo de trabalho remunerado na terra de alguém: o dono da chagra contrata uma pessoa, que se encarrega de convocar uma minga ou divichido para cultivá-la ${ }^{17}$. Já as yachajpa chagra são os lugares das chamadas "plantas maiores" de sanação, como Yagé, Shishaja, Borrachera, Chondures e outras. As chagras do sabedor, de responsabilidade dos taitas, são cercadas de cuidados. Situadas nos chamados lugares órfäos ou pesados, de preferência marcados pela presença de yako ñaui - olhos d'água -, elas são cuidadas por donos ou senhores dos lugares (suyumanda yaya). Por essa razão, somente pessoas convidadas pelos taitas podem entrar ali. Evita-se pisar nessas terras em "má hora", horários do dia em que os donos se tornam visíveis e podem adoentar quem os về ${ }^{18}$.

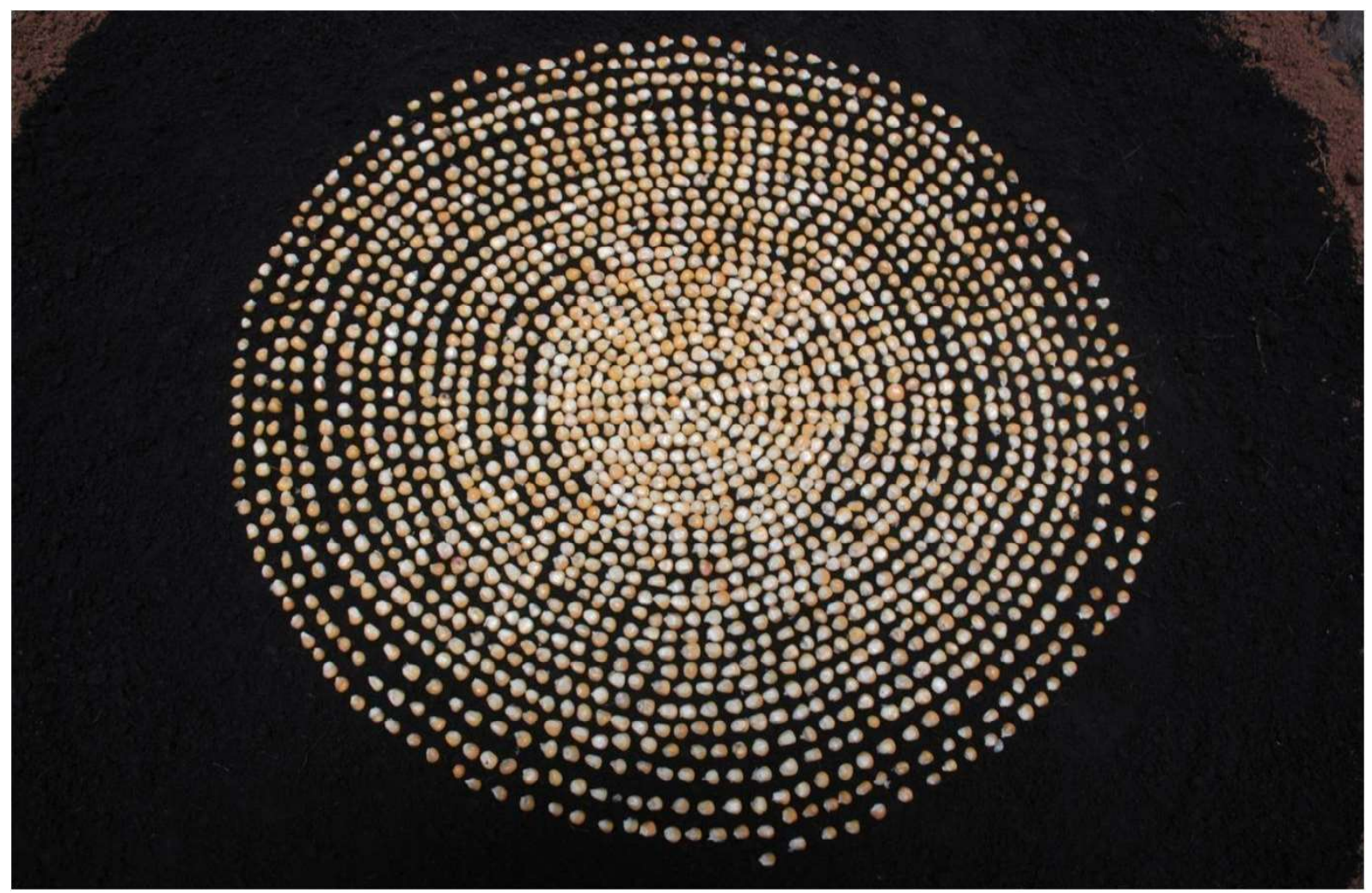

Imagem 10: Rosa Tisoy. Sem título [s.d.]. Fotografia (registro de performance). Acervo pessoal da artista

Em meio aos cultivos existentes, o milho tem uma importância preponderante, não apenas na alimentação dos humanos, mas também dos animais. Do milho saem inúmeras preparações, como envueltos (pamonhas), coladas (uma sopa doce de milho e frutas), mazamorra (canjica), arepas (discos de milho) e chugllu mote (caldo salgado feito com milho de canjica), entre outras. Também saem do milho as bonecas de palha que participam das brincadeiras de Atun Puncha (Dia Grande), a festa

17 Essas formas de trabalho, aliás, podem ser adotadas para outras tarefas. Em campo, pude acompanhar uma minga para a manutenção de um córrego: uma enorme fila de cerca de 50 pessoas, posicionadas ao longo da extensão do caminho d'água, iam retirando e ajeitando as pedras a fim de orientar seu curso - o que é fundamental para a irrigação das chagras. Quando fizeram uma pausa para o descanso, Dom Victor Revelo Quinchoa me ofereceu um pouco de chicha.

18 Benjamín costuma lembrar que, quando era criança, os maiores repetiam a recomendação de não ir à chagra do sabedor por volta das seis da tarde, das seis da manhã, ou das duas da tarde, horas em que aparecia por lá uma feiticeira (kuku mamita). "Dizer feiticeira é como dizer alguém que cuida do lugar", notou uma vez. 
do arco-íris. A chicha, fermentado de milho ${ }^{19}$ costumeiramente feita pelas mulheres, é a bebida mais importante entre os inga, partilhada nas celebrações e em dias de minga, entre as cerca de 50 ou 60 pessoas que atendem ao evento. É verdade que nos divichidos e conchavos pode-se oferecer chicha (além de carne cozida e mote) em quantidades pré-determinadas por pessoa, como forma de remuneração por guacho de terra trabalhado ${ }^{20}$. Mas as mingas são diferentes: como me contou Benjamín, elas são festas da semeagem e da colheita, quando as pessoas se reúnem para fazer sulcos na terra, homenageando-a por ter presenteado aos humanos uma porção de si. Assim, brinda-se a criatividade da terra, sua capacidade de produzir e perpetuar a vida.

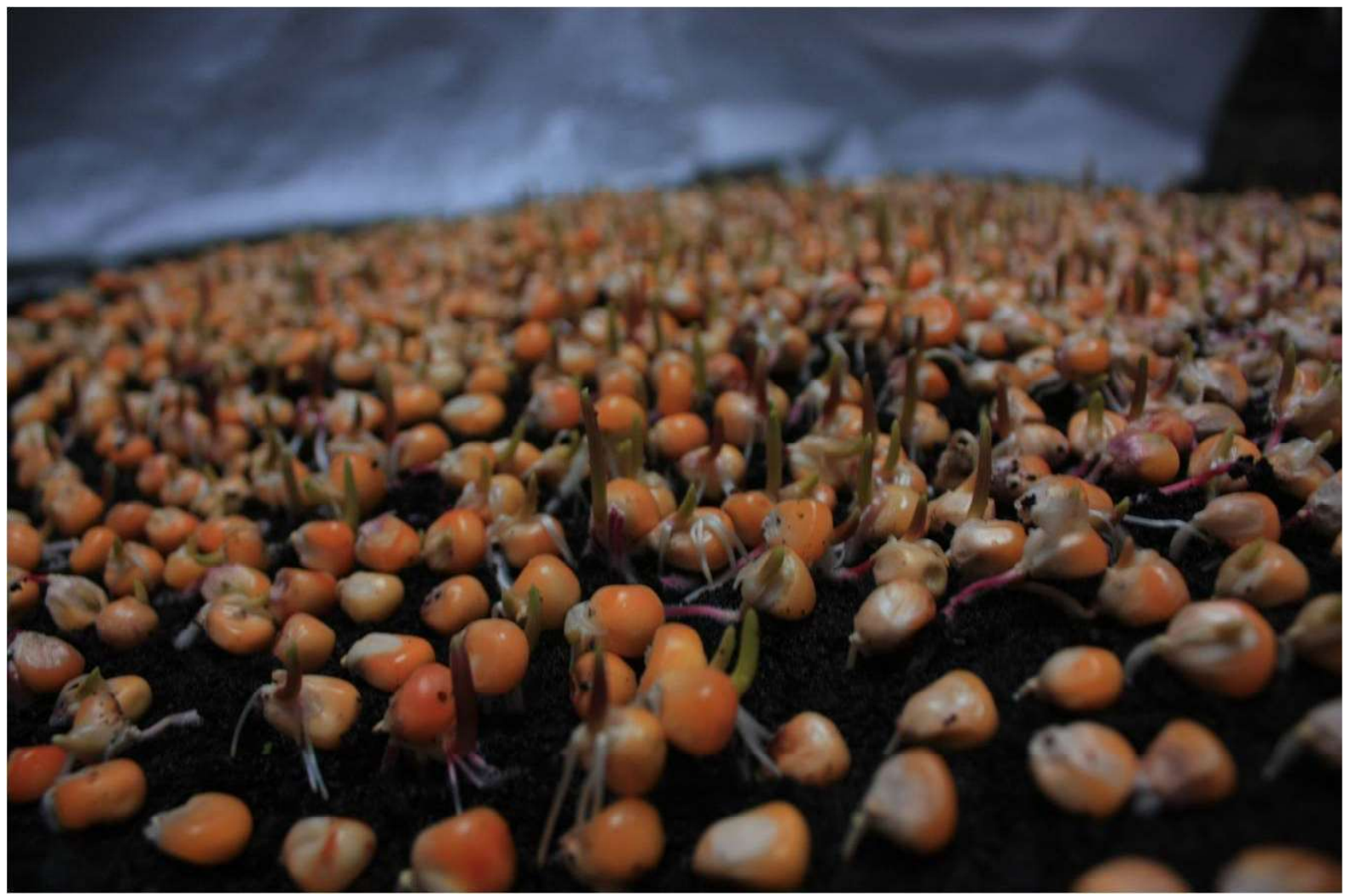

Imagem 11: Rosa Tisoy. Insalación [s.d.]. Foto (registro de instalação). Acervo pessoal da artista

Através da chicha que flui entre chagras, inúmeras relações são seladas. A partilha de samai está presente, na medida em que a bebida flui. Conforme aprendi, é graças a essa partilha de fluxos que firmam relações entre os viventes, que a terra vai fazendo a beleza do mundo em tudo o que existe. Em

19 Nem sempre a chicha é feita de milho e, na casa de mamita, também pude provar chicha de inhame - uma bebida preparada com inhames envelhecidos na terra por 15 anos, como me disseram.

20 Varas, guachos e braços são as unidades de medida adotadas. Duas braçadas, ou dois braços estendidos e $3 / 4$ de braço, equivalem a uma vara de bambu (tupudor). É o mesmo uma chacla ou chaclada, ou cerca de três metros. Um guacho corresponde a três braços estendidos. Uma quarta é o tamanho de uma mão aberta. Também se pode incluir dedos (suglla) na medição, sendo geme a distância da ponta do polegar à do indicador esticados. Suavita e Cañón (2005) classificam tipos de mingas conforme a exclusividade daquilo que é servido: chichaminga seria "paga" com chicha, mote e carne; minga, apenas com carne; iamtaminga, com madeira; aswaminga, apenas com chicha. Em todos os casos, essa remuneração é independente da chicha que flui livremente entre os partícipes do evento. Não encontrei tais diferenciações em uso; apenas pude ver a palavra minga sendo usada para aquilo que seria a chichaminga nessa classificação. 
cada vereda e entre elas, por sinal, essas relações avançam com o milho na forma dos muitos preparados e dos corpos que ele faz ${ }^{21}$ : os ingas, afinal, são "gente de milho", como me disseram algumas vezes.

A aprendizagem da chagra começa na infância. Por volta dos 12 anos, uma criança deve conhecer uma vasta gama de plantas. É nessa idade que ela começa a colher. O sangue das crianças menores é muito frágil e, caso cortem uma planta, podem “ter o sangue cortado”, como se diz. Por outro lado, o sangue de uma pessoa adulta pode ter força demais. É por essa razão que uma mulher menstruada não deve entrar em contato com a maioria das plantas de poder, que correm o risco de murchar nessas circunstâncias. "É como se tivessem sido escaldadas", me explicou mamita Mercedes uma vez, enquanto me mostrava suas chagras $^{22}$. Os Vinanes, por exemplo, "plantas para ter e presentear boa sorte” (Jacanamijoy Tisoy 1998: s.p.), secam muito rapidamente e, num contato com mulheres em seus períodos, podem se perder para sempre. Na composição das forças que mantêm o equilíbrio de uma chagra, contudo, também há plantas que protegem umas às outras, mesmo nesses casos. Uma das mais poderosas é a Borrachera ${ }^{23}$ (também chamada de Borrachero em outras partes da Colômbia), alvo constante de ataques de certos animais, como as galinhas, razão pela qual é protegida por telas. Já certas ervas aromáticas - cidreira, hortelã e outras - não são afetadas pelo sangue das mulheres no período menstrual.

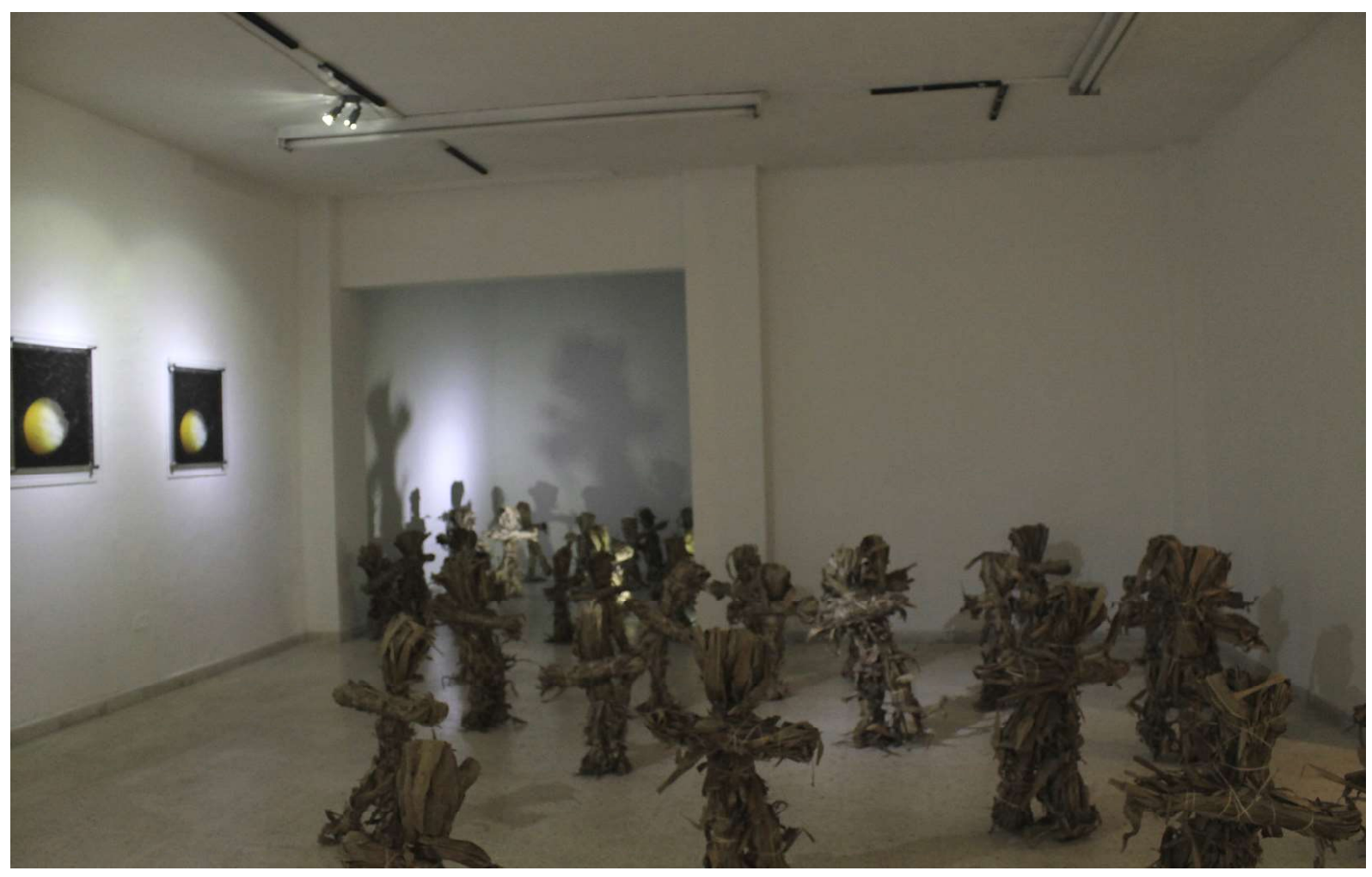

Imagem 12: Rosa Tisoy. Insalación [s.d.]. Foto (registro de instalação). Acervo pessoal da artista

21 Vem à mente, nesse sentido, um comentário de Peter Gow (1999 e 2001) sobre como os fluxos de cerveja de mandioca na iniciação das meninas piro são formas da agência feminina e atestam a capacidade de fazer coisas com design, assim como os fluxos de linhas pintadas e os fluxos de substâncias sexuais. Creio que também a respeito dos ingas se possa dizer que a chicha flui e faz gente, faz crescer corpos e relações.

22 Em minha experiência, foram mamita Mercedes e Teresita, esposa de taita Floro - Florentino Jacanamijoy -, que me mostraram mais de perto as chagras que se encontram sob seus cuidados. Além das chagras de sua casa, mamita também cuida da chagra de mama Conchita, sua mãe já falecida. Com Teresita, aprendi a plantar guasimba.

23 Pertencente às Brugmansia spp., da botânica ocidental. 
Aprendi com meus amigos que uma chagra é uma aprendizagem das relações entre substâncias que circulam, como o sangue e a seiva das plantas - fluidos que se afetam mutuamente. Como se nota, cortar uma planta é sempre um risco para quem a cultiva: interromper a circulação da seiva pode provocar o estancamento do próprio sangue. As mulheres, contudo, tem o sangue abundante e o produzem, estando mais protegidas desses efeitos. No período menstrual, o sangue pode afetar muitas plantas, fazendo-as perder sua seiva - a exemplo do que acontece com as plantas de poder - e também pode enfraquecer certos remédios que se fazem com elas.

Por outro lado, também se diz que ter o sangue abundante está imediatamente associado à capacidade das mulheres de fazer as coisas crescerem. Diz-se que, por isso mesmo, elas tem as mãos boas para o plantio do milho. Conta-se que as mãos "férteis" das semeadoras - e também das tecelãs - eram sopradas e urtigadas pelos taitas do passado que, desse modo, as protegiam e ampliavam seu alcance ${ }^{24}$.

Enquanto o sangue e a seiva se afetam mutuamente, o ventre e a terra podem ser considerados matrizes da criatividade, ou seja, é a partir deles que as coisas crescem, que se traz as coisas boas e belas para este mundo. A criatividade, enquanto conhecimento, se transmite no corpo, entre uma sabedora e uma pessoa que dela aprende. Depende da co-presença, de inúmeros processos pelos quais os corpos são feitos.

A terra, nesse caso, também recebe o nome de Pacha Mama - uma palavra de profunda ressonância nos Andes ${ }^{25}$. Uma vez conversei com Benjamín sobre isso. Na ocasião, ele notou que, embora o termo Pacha Mama venha sendo traduzido como Mãe Terra (que seria, por sua vez Alpa Mama), literalmente ele se refere a algo como Manto de Mãe. Pacha seria o nome do manto que recobre o ventre das mulheres - uma saia preta, amarrada por um chumbe. Nesse sentido, o termo Pacha Mama ensina que, na Terra e no corpo das mulheres, há lugares propícios ao crescimento. São lugares uigsa - palavra que remete ao ventre, ao começo, à origem. Os lugares para semear, os lugares para contar histórias, os lugares para curar e outros lugares de vida e pensamento são aprendidos e possuem sua própria criatividade, que flui nas maneiras com que as pessoas (uma grande variedade de seres que partilham do espaço) se fazem juntas, na presença umas das outras.

Em minhas aprendizagens, considero que o ato de enterrar a placenta após o nascimento de um bebê é como outra forma de semear a terra mas, neste caso, faz crescer crianças. A placenta deve ser depositada perto da tulpa, pois o calor do fogo será responsável por mantê-la aquecida, garantindo que fique forte e saudável, cercada de amizade. Às vezes, também se coloca uma ou duas brasas candentes sob o solo, a fim de ampliar o calor que chega à placenta. Penso que a terra funciona, assim, como um segundo ventre para a placenta, com influência direta sobre a vida da criança e seu crescimento.

Após o parto, a mulher deve tomar banhos em infusões de kuku sacha e aroeira, ou eucalipto, arruda e aroeira, a depender da situação. A primeira planta, também conhecida como animas sacha,

24 Em todo tipo de atividade, aliás, as pessoas maiores ensinam seus aprendizes a cuidar de suas mãos, cuidar para que elas não se tornem más, ou seja, não causem danos àquilo que tocam. As mãos boas são as mãos daqueles que se tornaram yachas - sabedores e sabedoras -, mãos capazes de trazer, mostrar e fazer sentir coisas belas.

25 Que tem recebido a atenção de inúmeros pesquisadores e aportes dos mais interessantes. $C f$. p. ex., Bastien 1978; Zuidema 1980 e 1989; Salomon 1991; Harris 2000; Mannheim e Salas Carreño 2015; Dean 2010 e 2015 ; Allen, 2015. 
tem o poder de espantar os espíritos dos mortos e, por isso, as cinzas de kuku sacha costumam ser espalhadas na porta da casa onde viveram ${ }^{26}$. A parturiente deve seguir uma dieta específica, que inclui água quente de guayabilla ${ }^{27}$, caldo de galinha e sopa de milho tostado com banana, leite e canela; ela evita comer carne de porco e pimenta, entre outros alimentos. A água de guayabilla, sobretudo, tem um papel importante para acalmar o sangue, fazendo-o descer e evitando a formação de coágulos. Também quando a placenta demora a sair, as parteiras suministram essa água às mães. A pimenta ajuda a aquecer o corpo do bebê, que agora já não se encontra mais no ventre da mulher. Por isso, no primeiro plenilúnio de sua vida, o corpo de uma criança é pulverizado com preparações dessa planta que, depois, é jogada num curso d'água. A fluidez do rio aporta força ao sangue da criança.

Os bebês recém-nascidos precisam ser carregados pelas mulheres, cujo sangue os fortalece: até os dois meses, à frente do corpo e, depois, nas costas, envolvidos pela baita (espécie de xale de lã de uma cor, com barra de outra, usado pelas mulheres inga). As crianças e as plantas muito jovens se parecem, porque dependem de muitos cuidados para crescer bem. Talvez não seja por acaso, nesse sentido, que se diga chugllu kiru (dentes de milho) aos primeiros grãos de uma espiga e aos primeiros dentes de leite de uma criança, ou ainda "milho moça” ou "árvore moça” à planta que já tem força o suficiente para resistir a uprinda uaira - vento de Aponte, que chega em rajadas em novembro e dezembro.

As substâncias que correm, como a água de um rio, o sangue e a seiva das plantas são vias por onde circula uaira (vento), a força que flui ${ }^{28}$. Em minha compreensão daquilo que se costuma traduzir como tempo - kutij -, entendi que essas substâncias podem fluir harmonicamente entre si, ou seja, no mesmo tempo. Mas também podem estar em tempos diferentes (sugsina kutijkuna), algo que remete a tempos de seres diferentes, entre outras coisas ${ }^{29}$. E que estar samai tem a ver com entrar nesse estado de

26 A palavra que se traduz como "espíritos" inclui duas categorias de seres: até onde pude perceber, $k u k u$ seriam seres de lugares conhecidos - o que inclui os senhores yaya. Um exemplo é salbaje kuku, o dono do Shishaja (uma planta de poder), com seus cabelos pontilhados que lembram o pólen. Aukas, por sua vez, seriam seres de lugares desconhecidos, que nunca fincaram sua existência na terra, por assim dizer. Aukas incluem, por exemplo, crianças falecidas antes ou pouco depois do nascimento. Como os Lugares de Vida e Pensamento são parte do mundo vivente, conhecer o lugar de onde vêm os seres faz entender sua força; desconhecê-lo faz vislumbrar perigos relativos à morte. A palavra auka (ou auca) tem muitas ressonâncias no mundo amazônico. Para mais informações, ver Taussig 1987; Reeve 1988; e Gow 1993.

27 Eugenia victoriana, na botânica ocidental.

28 Para uma análise da hematologia amazônica e suas relações com o gênero, ver Belaunde (2006). A autora recorda a importância do sangue para a produtividade entre diferentes povos amazônicos: a boa circulação do sangue produz alimentos, objetos, palavras, aromas, crianças e outras coisas - obras do "pensamento", cujo centro seria, em alguns casos, o coração e que, em outros, está disperso no próprio sangue que flui. O sangue, por sua vez, é sempre formado pelas experiências da vida de uma pessoa, é memória incorporada. E o pensamento está intimamente ligado à memória dos parentes, à nutrição e ao cuidado. O sangue das mulheres é seu poder e não fraqueza - como às vezes se supõe -, pois a partir dele nascem também os homens. Em meu campo, como fui aprendendo, o pensar bonito passa pela circulação de uaira e do sangue - o que vai ao encontro desses entendimentos.

29 Algumas tardes se passaram em conversas com Benjamín sobre kutij. Ele me explicou que, apesar de algumas pessoas terem pensado o "tempo" como algo que se devolve (p. ex., Guava 2003), seria mais acertado dizer "o que regressa", ou "regressa a si mesmo" - o que, aliás, mostra o desenho Kutij, no chumbe. Além disso, não há somente tempos diferentes (sugsina kutijkuna - quem regressa como outro), como também tempos iguais (sugllasina kutijkuna - quem regressa como um só). Há nisso uma sabedoria sobre como as pessoas se fazem através de inúmeras relações e de como o bonito fazer - suma ruray - também acontece como uma relação entre tempos de seres e coisas distintas. 
partilha de um tempo, de um lugar. É uma forma de conhecimento, que passa por entender os outros seres como "possuidores de força e vida”, como ensina Benjamín.

O contrário pode suceder. Há pessoas e lugares "pesados" que estancam o sangue, tornando o ar pesado - o que é conhecido como mau vento ou mau ar (kuku uaira). Isso costuma se dar nas cercanias da morte, em lugares onde alguém faleceu ou onde fetos ou recém-nascidos foram enterrados. $\mathrm{O}$ mau vento requer atenção especial e, para curá-lo, são tomadas medidas como, por exemplo, a defumação do corpo acometido por esse mal com ervas aromáticas, como o copal (uma resina de árvore), ou banhos de ervas, como a urtiga. No passado, recomendava-se curar o mal vento com um banho de ambi yako, um redemoinho do rio Tamauca.

A fumaça é um elemento importante para espantar os maus espíritos e o tabaco para os cuidados com o bebê e durante o parto. Antes de começar a massagear a barriga de uma gestante, a parteira aquece as próprias mãos com tabaco. Quando o cordão umbilical é cortado, amarra-se o umbigo da criança com um fio de lã vermelha e, então, a parteira sopra seu corpo com fumaça de tabaco, para então amarrá-lo num chumbe pela primeira vez.

As águas são como o sangue da terra, que brota de seus yaku ñaui (olhos d'água) e se transforma em sangue e seiva, nos corpos dos outros seres. A criatividade das mulheres e das plantas passa por sua capacidade de produzir sangue e seiva, por onde e de onde a vida flui. Tais poderes remontam a um tempo muito antigo, quando ocorreu a primera fecundação.

Conta-se que antes, a terra era escura e as pessoas tropeçavam por todas as partes sem enxergar, apalpando os caminhos em busca de alimentos. Já existiam todos os seres que existem hoje, mas não o conhecimento. Em certa ocasião, um grupo de pessoas topou com num cipó e resolveu prová-lo. A planta foi dividida em dois pedaços: o primeiro pedaço foi comido pelas mulheres, que então tiveram a menstruação. O segundo foi comido pelos homens. Nesse momento, o cipó foi subindo alto, até fecundar uma enorme flor no firmamento. O céu aclarou e começaram a aparecer os contornos de todas as coisas. Da flor, nasceu o sol e dele começaram a descer homenzinhos, cada qual com um instrumento musical diferente. Pouco a pouco, os sons emitidos por esses instrumentos foram virando cores. Então, os homenzinhos, já dispersos pela terra, foram imprimindo as cores em todos os seres que havia. Em certos seres - os humanos -, a música virou linguagem falada. O cipó, como explicam, seria o Yagé; a flor, a Borrachera ${ }^{30}$.

Nesse mito, o cipó confere às mulheres a capacidade de produzir sangue e semeia a flor primordial. Os homens, por sua vez, aprendem dele a traçar caminhos por onde vão descer homenzinhos, que fazem os sons, as cores e a linguagem. Penso que seria possível dizer, por meio dessa história, que o conhecimento ensinado pelas plantas é, assim, a própria criatividade: a vida, tornada visível na forma de seres que tem cores, sons e linguagens sob a luz do sol, vida que se perpetua na medida em que mulheres e homens sabem concebê-la, trazendo à tona novos seres dotados de som, cor e linguagem.

A importância do milho, entre os cultivos da chagra, também remonta à essa existência vivida sob o sol. O nome "milho de sol” (sara indi), que se dá ao milho maduro, refere-se ao milho ao qual o

30 Registros dessa história se encontram em Jacanamijoy Tisoy 1998 e 2017; e Pinzón e Suárez 1979. 
sol transfere sua cor. Ao herdar essa cor, o milho se torna capaz de imprimir vida aos corpos de todos os seres que dele partilham, fazendo-os crescer e mostrar-se belos e saudáveis ${ }^{31}$.

Como me ensinaram em inúmeras ocasiões - e como costuma mostrar Benjamín - o conhecimento de verdade entra primeiro pelo ventre (uigsa, correspondendo a ventre e útero) e, ao passar pelo coração, se converte em samai. Aí se encontra a capacidade de viver bem (suma kaugsay), que guarda conexões profundas com o princípio do pensar bonito ou pensar bem - suma yuyai. Suma é, aliás, uma palavra se refere ao que é bom ou faz bem e ao que é bonito, ao mesmo tempo. Benjamín, que aprendeu o pensar bonito de seu pai, o taita Antonio Jacanamijoy - "pensar bonito, com o coração contente" -, diz que pensar bonito não é uma doutrina de conduta. Também é diferente de sentir: sentir é algo momentâneo, enquanto pensar é o que fica, uma aprendizagem que se revela quando alguém se torna maior - yacha, sabedor. Por isso mesmo, quando o pensamento dos maiores flui na forma de palavras, elas sempre chegam ao coração de quem sabe escutar (uiay).

O pensamento vem do conhecimento, é uma capacidade adquirida no corpo, a capacidade que uma pessoa tem de ensinar e curar as demais de todas as coisas que as afligem. Quando alguém recebe comida, cuidados e palavras dos maiores, prepara seu corpo para um dia poder ensinar. Só ensina quem sabe estar samai.

Numa conversa com mamita Mercedes, ela traduziu uigsa por matriz. Esta forma me parece das mais interessantes: ao lembrá-la, penso que uigsa seria uma matriz da criatividade que perpetua a vida. Vim a entender que valor das chagras como matrizes, Lugares de Vida e Pensamento das mulheres e das plantas, é atestado por sua capacidade de dar coisas boas. Esse cuidado se manifesta em tudo o que emana de seus corpos, na beleza das plantas, das pessoas e dos animais que se nutrem desse trabalho.

\section{Chumbe Suyu}

Gostaria também de falar um pouco sobre o chumbe. Trata-se de uma faixa de lã tecida por mulheres, que conta uma história através de mais ou menos 100 desenhos distribuídos lado a lado. A faixa costuma ter cerca de quatro ou cinco metros de comprimento e três cores, mas pode ter duas ou mais de três (o que é considerado algo excepcional). Todas as crianças usam chumbes até determinada idade. Passado esse tempo, somente as meninas continuam fazendo uso da faixa. Há, entretanto, os chamados kari chumbe, chumbes de homem, que costumam ser usados pelos taitas sobre o ventre, os punhos e em torno da cabeça - sobretudo quando estão curando enfermidades, ou nas cerimônias com plantas de poder.

Essa faixa sustenta o corpo e o segura pelo ventre, qual planta agarrada à terra, além de ajudar a ter e fazer força. Quando os bebês são envolvidos pelo chumbe após o nascimento, eles tentam soltar a faixa; assim, fortalecem o corpo e aguçam a visão. Uma pessoa, dependendo de seus anos, usa muitos chumbes sobrepostos, ao mesmo tempo: isso é uma amostra de seu conhecimento, que vem com a idade.

31 Entre os kamëntšá, o milho também é visto como uma transformação do sol. Em poema dedicado a seu filho, o poeta Hugo Jamioy Juajibioy (2010: 33) escreve: “Cantam os raios de seu espírito/Fios dourados desprende a casa de suas razões/anunciam sabedoria/Crece e crece a cada amanhecer/com a força de cada fragmento de sol feito milho". 
Há 38 desenhos conhecidos ${ }^{32}$, por exemplo, o sol, a mulher, o homem, a criança, a água e os rios, a chagra, o milho, as plumagens e o colibri, entre outros. São grafismos que vêm de tempos distantes e que seguem sendo usados até hoje, da mesma maneira. Não se criam novos desenhos. As histórias que importam seguem sendo contadas por meio das figuras existentes.

Aprendi com Benjamín - o maior pesquisador do chumbe inga ${ }^{33}$ - a conhecer os desenhos do chumbe. O desenho-base é um losango e se refere a uigsa como um lugar de vida que, como os outros lugares, organiza-se a partir de quatro pontos cardeais - norte, sul, leste e oeste. Os demais desenhos são variações a partir do losango. O principal deles é a "flor de ventre" ou "mulher grávida”, que - como conta Benjamín, "une homem e mulher, flor e querer", como um ser no mundo.

A faixa não só envolve o ventre, mas nasce dele: para tecer à maneira antiga, amarra-se outra faixa sobre a barriga. $\mathrm{Na}$ altura do umbigo, passam-se por dentro desta faixa os fios de lã que serão utilizados, já arranjados em uma trama, dividindo-os em duas partes iguais. A outra ponta dos fios de lã é amarrada a uma superfície mais elevada, como por exemplo, um ponto no tronco de uma árvore, uma forquilha ou o degrau de uma escada, e, com os fios bem esticados, começa-se a trabalhar. A trama, por sua vez, é feita na terra da chagra: os fios vão sendo envolvidos em três estacas no chão e amarrados, triangularmente. A chagra é um dos lugares mais importantes para tecer, mas também se pode tecer em casa, uma vez que se tenha a trama.

Além desse método, também se utiliza o tear. Benjamín certa vez comentou que os missionários capuchinhos ${ }^{34}$ quiseram impor o uso do tear, porque consideravam indecente a prática de passar a faixa pelo ventre. Mas com essa mudança, um aspecto importante do tecido se perde, como ele explica: no método antigo, "o chumbe flui na vertical, mas a trama começa na terra". Tecer, em inga, disse Benjamín, é auay e aua quer dizer "para cima” ou "acima”. Está aí o sentido do movimento, que acontece como se os desenhos fossem brotando de uigsa uarmi, em proximidade com o chão. É importante que eles sigam uma linha ascendente, que passa por uigsa uarmi (ventre de mulher), compondo um fluxo para o alto. Nisso, penso que há uma aprendizagem: uigsa uarmi, assim como a terra, sendo lugares a partir dos quais as coisas crescem, também propiciam o crescimento da faixa e a criação de seus desenhos.

Na primeira menstruação, uma menina recebe um chumbe "aquecido", ou seja, um chumbe de sua avó materna ou, na ausência dela, de outra mulher próxima, da mesma geração. Através da faixa, a avó transmite algo de si (puangui) à jovem que ingressará na vida adulta. Nesse momento, a menina também pode começar a tecer seus próprios chumbes. $\mathrm{O}$ conhecimento plasmado nessas faixas per-

32 Benjamín Jacanamijoy, autor pioneiro do principal estudo sobre o tema, registrou 37 desenhos feitos pelas abuelas tecedoras de quem aprendeu, abrindo caminho para que, depois, outras pessoas retomassem esse conhecimento. Em tempos recentes, Ángel Mojomboy Cuatindoy, professor de cultura inga de Uaira/San Andrés, incluiu outro desenho, Añango (Formiga), ao conjunto. Cf. Jacanamijoy Tisoy 1998, 2001, 2014 e 2017; Cuatindioy 2015. Chasoy e Bastidas Jacanamijoy 2007 também escreveram sobre o chumbe.

33 Cf. Jacanamijoy Tisoy 1998 e 2017.

34 Os primeiros espanhóis chegaram ao Valle de Sibundoy na expedição de Juan de Ampudia e Pedro de Añasco, em 1535. Já os capuchinhos vieram em 1893, permanecendo na região até 1969. Em 1904, o Estado colombiano criou a Prefeitura Apostólica de Caquetá e Putumayo, por meio da qual outogarva poderes de Estado aos capuchinhos, que então assumiam o governo de uma área vastíssima, habitada por uma enorme quantidade de povos indígenas, abrangendo o Alto e o Baixo Putumayo. A colonização resultou em inúmeras tragédias, como os trabalhos forçados, a perda de terras ancestrais e do direito de ir e vir, mortes e suicídios entre os ingas e kamëntšás do Valle. 
tence a uma mulher e somente ela pode passá-lo a outra. É um saber guardado na faixa à maneira de sua detentora e que ela adquire - como todo conhecimento que importa - pelo ventre, ao vestir pela primeira vez um chumbe aquecido. Cada desenho, afinal, é um tipo de conhecimento que chegou ao coração e, com isso, recebeu uma forma condizente com a história que se conta. No momento em que presenteia a faixa, a mulher mais velha mostra, no corpo da jovem, sua criatividade: um corpo enfeitado de saber e calor. Nesse sentido, o chumbe é a partilha de samai entre duas mulheres que, por meio da faixa, conectam suas histórias, tornando visível o processo de transmissão dessa criatividade - capacidade de conceber e fazer as coisas crescerem - como vínculo entre elas ${ }^{35}$.

O conhecimento não é algo que se aprende apenas copiando um padrão, mas sim algo acontece enquanto alguém tece, algo que se recebe no ventre e, com os anos, fica guardado no coração. Aprender, nesse sentido, exige que a tecedora saiba conceber desenhos em seu corpo; para conseguir, ela não deve copiá-los de outros lugares, mas desfiar e refazer o chumbe até que eles aconteçam por si sós. $\mathrm{O}$ ato de desfiar, diz Benjamín, é "voltar à origem do conhecimento" - ao uigsa suyu. Ao passar aquilo que aprendeu às mais jovens, uma maior completa o caminho que as fez crescer: agora, é a menina quem perpetuará essa memória em outras vidas.

Entendo a criatividade, como escrevi anteriormente, como algo que torna um lugar de vida e pensamento um uigsa, uma matriz capaz de fazer coisas boas. É também, no modo como vim a apreendê-la, a maneira com que as coisas se transformam, através da qual a vida vai se perpetuando na forma de corpos que crescem e fazem crescer os demais. Além disso, a criatividade nasce numa terra de muitas pachas, uma combinação de mantos sob os quais a existência flui, cada qual com seus tempos particulares - tempos de gente, de plantas, de água e de outros seres. Creio que Rosa, num pequeno poema que incluiu em seu trabalho de conclusão de curso na Universidade - caderno fabuloso de escritos, colagens e desenhos -, exprime a maneira com que a criatividade flui entre a terra (“Terra” em maiúscula, no texto) e o corpo das mulheres.

Habitou um dia em mim um ninho, um ninho que retumbava a ecos de mamãe... ecos da Terra que floresciam em meu coração, ecos que germinaram junto com minha alma... de caminho ao infinito.

Leio o poema e vislumbro a maneira com que um corpo pode compor, com a Terra, uma existência infinita, cuja amplitude só pode ser abarcada na medida em que a criatividade flui nas relações entre os seres, no alento que cada um vai recebendo dos demais e aprendendo, no coração.

35 Creio que seria possível dizer, a esse respeito, que avó e neta refazem, juntas, a relação que as torna parentes e que as une como parte da mesma história. Como se sabe, Peter Gow (1997, 1999, 2001) e Marcela Coelho de Souza (2002 e 2004) percebem o quanto, nos contextos ameríndios, a humanidade está ligada ao fato de saber-se parente de alguém. Em outro texto, Gow percebe o design como efeito da produtividade social das mulheres piro e manifesta como beleza nos corpos das outras pessoas. A importância da nutrição e do cuidado na produção de parentesco, bem como a "generização" desses processos é destacada por McCallum 1989, em diálogo com Gow (1989 e 1991). 

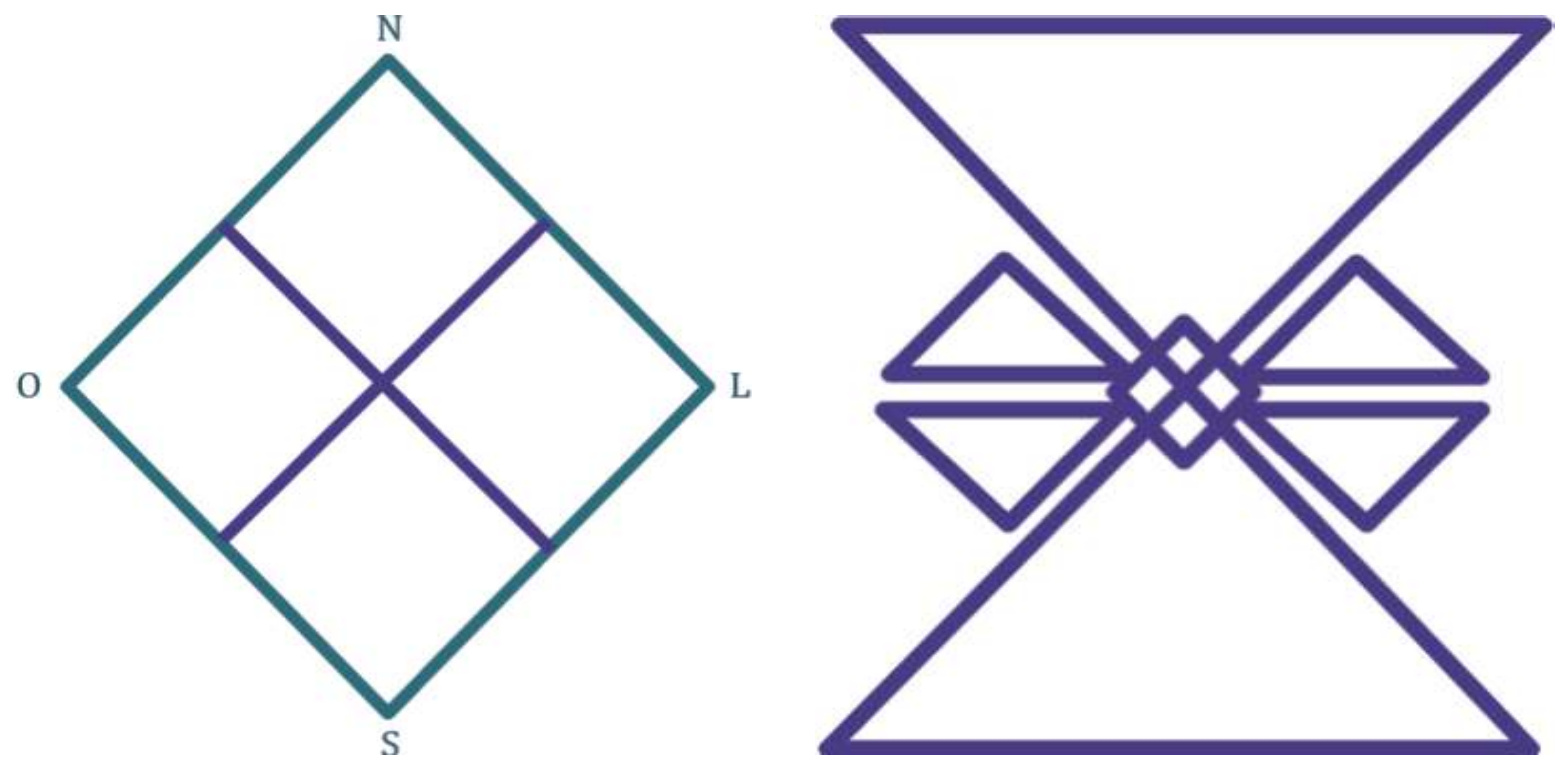

Imagem 13: Uigsa Suyu | Suyu Kallarij | Kaug- Imagem 14: Uigsa Tujtu

say Suyu. Lugar de Ventre | Lugar do que Começa Flor de Ventre [Mulher grávida]

| Lugar de Vida. (elaboração própria, a partir de (elaboração própria, a partir de Jacanamijoy Jacanamijoy 2017) 2017)

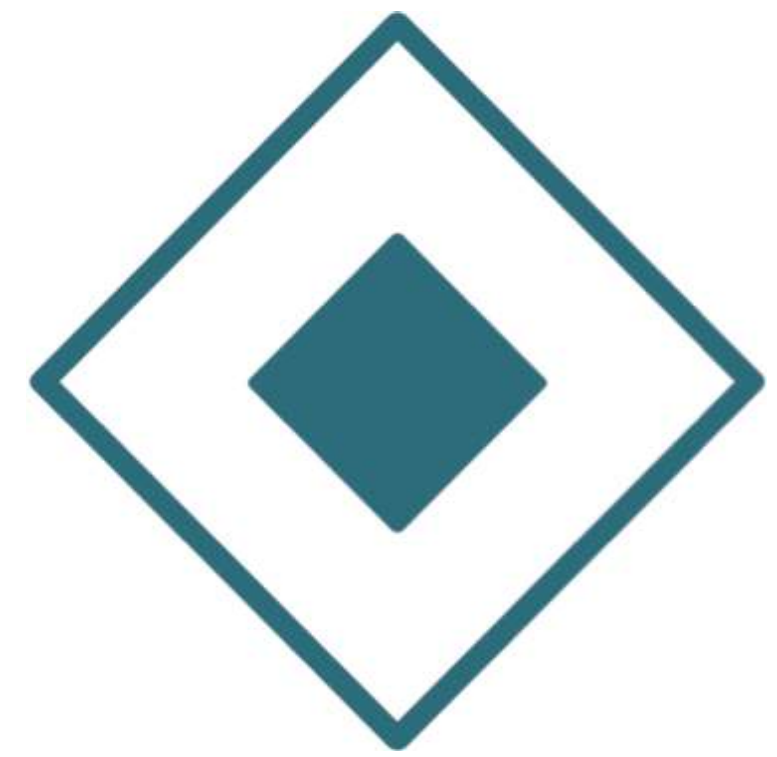

Imagem 15: Samai

Alento

(elaboração própria, a partir de Jacanamijoy 2017)

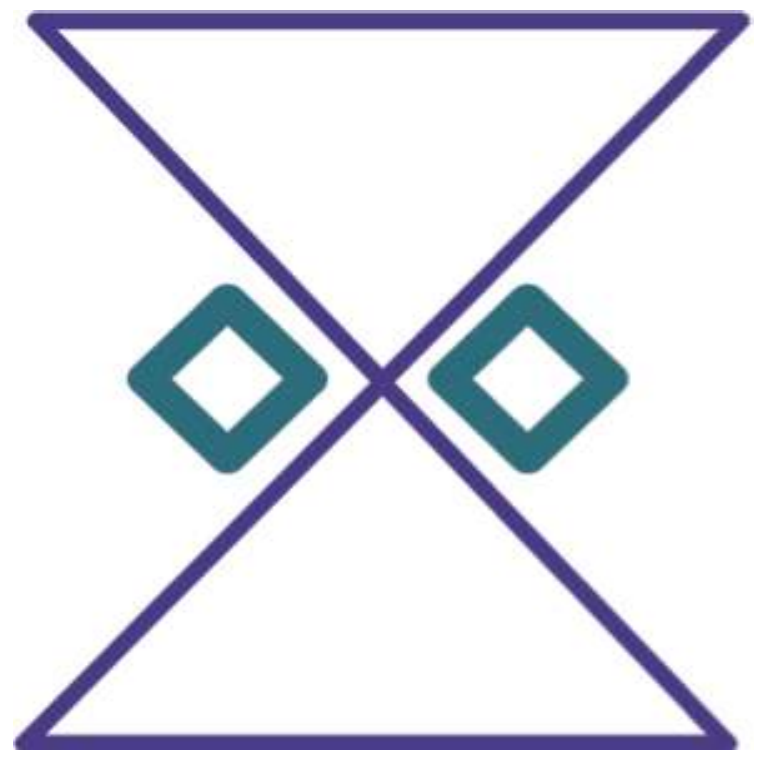

Imagem 16: Uigsa naui

Olhos de Ventre

(elaboração própria, a partir de Jacanamijoy 2017)

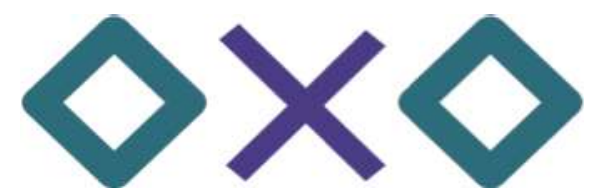

Imagem 16: Chaska Nauimurukuna Olhos de Estrelas (elaboração própria, a partir de Jacanamijoy 2017) 


\section{Suma Yuyay}

Benjamín e Carlos Jacanamijoy, mas também Rosa e a artista inga-kamëntšá Tirsa Chindoy ${ }^{36}$ me disseram que não há, entre os inga, uma separação entre arte e vida. Ambas dizem respeito às maneiras de conceber, fazer crescer e perpetuar aquilo que existe. Aliás, não há uma palavra para arte. Dos termos que traduzem atividades artísticas, há yuyay, - pensar -, por exemplo, ou muscuy - sonhar. Esses não são atos puramente mentais, mas atos que perpetuam vidas, porque um sonho ou pensamento pode curar pessoas, afetar corpos ou provocar acontecimentos. Disto decorre a importância do preceito de suma yuyay - pensar bonito ou pensar bem -, para fazer com que coisas boas aconteçam. Conforme me contou Benjamin certa vez, suma yuyay pode ser aproximado a suma ruray, algo como fazer bonito ou fazer bem. A arte, por sua vez, seria algo como um "fazer-pensar bonito/bem". "Esse", disse ele, "é um princípio de criatividade"; outro princípio seria apamuchii, trazer bem, como sabem fazer as semeadoras e as parteiras; e kallarijchii, originar. Por fim, pugliay - brincar - refere-se à capacidade de provocar transformações naquilo que nos cerca e, assim, quando alguém sabe brincar, também pinta, pensa, sonha, cria, traz coisas boas ou origina coisas boas para este mundo.

Assim, viver bem (ou viver bonito) é um efeito do pensar bonito (ou pensar bem) e, por isso, se diz suma yuyay, suma kaugsay, "bonito pensar, bonito viver”. A palavra suma, a propósito, se traduz duplamente como bem e bonito, acentuando a coincidência entre os dois termos. Seguir o preceito do suma kaugsay exige sensibilidade, habilidade e conhecimento para fazer circular samai, a fim de mostrar coisas belas, perpetuar a vida daquilo que existe ou provocar bons acontecimentos. Penso que suma ruray, nesse sentido, poderia ser visto como uma espécie de técnica do bonito pensar ${ }^{37}$.

Uma chagra repleta de variedades de plantas, o milho dourado e suas preparações, assim como uma mulher jovem que emana beleza no uso de um chumbe são manifestações da criatividade que passa pela capacidade das mulheres de pensar/fazer bonito e viver bem. Viver bem, por sua vez, envolve um cuidado com todos os seres que co-habitam os lugares de vida de uma pessoa.

A criatividade da terra produz uma série de transformações que vão da água à seiva das plantas, ao sangue e às novas vidas que surgem dessas substâncias. As próprias sementes são parte dessas transformações - uigsa das plantas. Em inga, sêmen e semente não tem origem na mesma palavra, como em português e outras línguas neo-latinas: muyu ou ñaui podem se referir a semente, sendo ñaui a palavra que se refere mais comumente a olho; sêmen ou esperma seriam yumai. Deixo-me pensar, a partir daí, que as sementes, talvez correpondam a olhos férteis da terra, nas plantas, assim como os olhos d'água (yaku ñaui). Tais metáforas encadeiam um fluxo que localiza o valor da criatividade como concepção (Strathern 1995) - o que poderia ser visto como uma contribuição das mulheres para a perpetuação

36 A conversa com Carlos foi numa reunião em sua casa, no dia do passamento de taita Antonio Jacanamijoy. Em sua memória, tomamos Vinan - um preparado de plantas medicinais.

37 Assim como Benjamín, a artista inga-kamëntšá Tirsa Chindoy usou a expressão suma ruray para referir-se à arte (que não se resume àquilo que se define como arte no ocidente), em um de nossos encontros em Sibundoy. No Equador, a artista Manai Kowii (2016) tem se dedicado a pensar esse termo na compreensão da produção artística kichwa-Otavalo e também o coletivo Sumakruray o utiliza como forma de afirmação de um fazer artístico particular. Sumak, como me explicou Benjamín, é mais do que bom, é boníssimo, belíssimo. 
da vida, mas também como algo que depende das maneiras com que a terra vai se multiplicando nos corpos através de muitos uigsa e muitos olhos que veem uns aos outros, através dos quais a vida vai ganhando chão.

Penso, afinal, que as obras de Rosa também emergem como manifestações desse fluxo. Certa vez, conversamos sobre Kanimi Alli Uiñangapa e Sara Indi. Nessa conversa, ela associou ambas as obras a dois tipos de memória: suas memórias de uma infância passada junto ao milho e as memórias de um corpo como "território de vida”, um corpo-mãe que também nasce de um grão de milho.

Num momento, comecei a lembrar como que a infância, quando corria pelas plantações de milho, quando acompanhava minha mãe nos plantios, as colheitas e como o milho começou a formar parte importante para minha vida, sempre esteve ai presente, no alimento e em muitas partes. Então comecei a lembrar, a fazer memória, mais que tudo, da minha infância, e logo como que comecei a colar grãos de milho sobre o corpo, mas fusionando o milho. Minha filha também foi uma das que me ajudavam a colar o milho e fez parte também da criação da obra -, mas sempre falávamos, com minha filha, que o corpo se convertia em algo bem bonito, algo bem sagrado, como mãe e como território de vida, que é o corpo. E assim começaram a chegar outras coisas à minha mente e como o milho se converteu em parte importante para minha vida, como semente, comecei a fazer registros fotográficos do milho, como sessóes fotográficas, e comecei a fusionar com fetos, como o nascimento, os nove meses de gestação que vêm a ser bem importantes para a vida, desde aí começa a vida, desde o momento em que somos engendrados no ventre de uma mãe, e nas duas últimas fotografias dos nove meses de gestação, aparece meu corpo na semente de milho, então, pois, a mensagem era também como nos convertemos nessa bonita semente para o universo, que vão dando mensagens bonitas e como nós vivemos nessas sementes, crescemos nessa semente e viajamos nela, mas sempre vivendo bem e compartilhando coisas bonitas para o universo, para as demais pessoas que nos rodeiam (ênfases minhas, tradução livre).

Kanimi Alli Uiñangapa pode ser traduzido como "sou lugar onde as coisas já crescem" (uiñay= crescer; uiñachij = fazer com que se crie, criar; uiñarij = germinar, nascer semente, criar-se). Em espanhol, Rosa (Tisoy 2013) nomeia esse trabalho de Sou Boa Semente, vinculando a ideia de semente ao corpo da mulher e à geração da vida:

Sou Boa Semente refere uma conexão com a terra, com cada um dos elementos essenciais da natureza, que assim como a semente do milho, sua transformação e sua linguagem de poder, a semente, apresentam um acúmulo de cores próprio à proximidade com o sol; o que a partir de uma significância pessoal é o arraigo à terra, assim a vida é a semente da qual se cuida desde o momento de nossa gestação, é onde nasce a vida, convertendo-nos na bonita semente do universo (Tisoy 2013 [s.d.]).

Sobre Sara Indi (Milho de Sol), em que o milho recobre o corpo, formando desenhos - como num chumbe -, ela diz: 
O corpo se converte no vínculo e a forma que, recriada pela imaginação de querer plasmar um símbolo para poder dar igual significado ao corpo e ao milho, com a ajuda das diferentes culturas, se aproxima à conexão através dos cultivos da semente, o cuidado e a colheita, milho sagrado do sol. O corpo é o mais puro, evoca o nascimento da vida, também me provoca a lembrar e imaginar o corpo, talvez deixá-lo ver numa íntima relação com a natureza, a partir da semente de milho, um corpo como objeto similar de beleza, de forma ou expressão (idem, ibidem).

Está plasmada nos dois trechos, assim como na fala acima, a relação primordial que une a terra - sua criatividade - às mulheres. Também está aí uma maneira de perceber a beleza como algo que se torna visível através dessa relação.

As passagens também me fazem pensar que, num mundo de olhos-sementes ñaui-muyu, olhos que veem podem ser produtores de beleza. Inspirada pelo poema de Rosa, falei anteriormente sobre a possibilidade de uma existência infinita, na medida em que corpos e terra se conjugam. Considero que, no trabalho de Rosa, essa existência se estende como um encontro de olhos que veem e que convergem em desenhos ${ }^{38}$.

Ao apresentar o chumbe, Benjamín ${ }^{39}$ me mostrou que uma das aprendizagens ali contidas é que os olhos percorrem toda a amplitude da existência. Eles já existem desincorporados, antes ainda do nascimento, como mostram pelo menos duas figuras: Uigsa Naui - Olhos de Ventre - e Chaska Nauimurukuna - Olhos de Estrelas [imagens 15 e 16]. Os olhos de ventre são o início de um novo ser, que chega a uigsa uarmi (ventre de mulher) como um ser que vê. Os olhos de estrelas são os olhos dos maiores que já passaram por esta terra - e também o olhar que deles se herda. Como costuma dizer Benjamín, este olhar é, afinal, "um alento que nos permite ver mais além do horizonte". A sobrevivência dos olhos após a morte e sua existência antes da vida estão na origem da capacidade de se relacionar ou saber-se um par de olhos que reconhecem outros olhos em tempos diferentes, mas também de olhos que zelam pelos demais. Creio que não é por acaso, nesse sentido, que os bebês vão firmando seus olhos físicos, aguçando a visão, no exercício de soltar-se de um chumbe: assim, eles preparam os olhos para a vida num corpo terrestre.

Como aprendi a vislumbrar, Kanimi Alli Uiñangapa faz aparecer uma relação entre corpo e semente, como parte dos processos de crescimento da vida; desse modo, a série também joga com a visão, engendrando muitas perspectivas ${ }^{40}$. O olho-semente de milho, os olhos da artista que nasce dela e os olhos de quem os vê, todos são parte de uma terra de olhos - olhos d'água, olhos muyu, olhos de todos os seres que a habitam. Talvez aqui se pudesse dizer que a beleza também nasce como fruto desse encontro de visões, pois reside nas relações que se desdobram na co-presença dos seres que ali se veem. Fazer crescer vidas, imagens e relações entre os seres que partilham de um espaço em muitos tempos é crescer também, tornar-se maior. E uma pessoa maior é alguém que refaz a experiência da beleza nas

38 Sobre o papel da visão e da perspectiva no mundo andino, ver, p. ex., Allen 1998, 2002 e 2015.

39 Em inúmeras ocasiões. Isso também se encontra em Jacanamijoy Tisoy 1998 e 2017.

40 Haveria, nesse sentido, diálogos possíveis com a questão da perspectiva, apresentada nos trabalhos clássicos de Stolze Lima 1996 e Viveiros de Castro 1996, entre outros; essa aproximação, entretanto, foge aos limites deste artigo. 
gerações vindouras, que perpetua as existências visíveis e as torna belas/boas - fortalece outros corpos, mãos, olhos e pensamento para viver bem, fixando-as numa forma plena a fim de que possam continuar seu trabalho.

A criança na chagra aprende a respeitar e entender a beleza que aparece entre as coisas que crescem. Sofía, quando colava sementes no corpo de sua mãe, também a semeava e a tornava um corpo repleto de olhos capazes de florescer, formando desenhos. Entre os olhos do público, os de Sofía, os de Rosa e muitos olhos-sementes de milho, há um corpo-terra finamente desenhado. É um corpo que, como escreve Rosa, se deixa ver a partir da semente de milho, formado com a ajuda das diferentes culturas; um corpo que, afinal, se torna belo sob muitos pontos de vista.

Ao virar uma série fotográfica, a performance ganha outras dimensões. Quando apresenta Sara Indi, Rosa inclui duas frases sugestivas de teóricos da fotografia que falam da variedade de modos de ser contidos numa foto, assim como das relações entre o que se vê, o que se deseja ver e o direito de ver. A primeira é de Roland Barthes: "Frente à objetiva, sou de uma só vez; aquele que creio ser, aquele que gostaria que creiam; aquele que o fotógrafo crê que sou, e aquele de quem se serve para exibir sua arte" (Barthes 1980: 29, tradução livre) ${ }^{41}$. De Susan Sontag, ela anota: "As fotografias alteram e ampliam nossas noções do que vale à pena olhar e do que temos direito a observar. São uma gramática e, sobretudo, uma ética da visão" (Sontag 1977: 3, tradução livre) ${ }^{42}$.

O trabalho nas chagras produz corpos, milho e outros seres vivos como amostras de um cuidado que reflete os bonitos pensamentos das semeadoras. $\mathrm{O}$ trabalho de Rosa opera no limiar de uma continuidade entre os corpos e a terra, em que ambos se modelam mutuamente, fazendo pessoas, alimentos, remédios, animais e outros seres ou coisas - e nisso se aproxima do semear e do tecer. Como mulheres, seríamos lugares de vida, terra capaz de produzir e germinar sementes, mas também as próprias sementes e tudo aquilo que elas podem criar. As transformações entre terra e semente aparecem, afinal, entre outras coisas, como uma história do parentesco, em que a mãe pode nascer da filha que a semeava com os grãos de milho, ao mesmo tempo em que a filha vai aprendendo os desenhos de chumbe no corpo de sua mãe: aprendizagem das relações que percorrem muitos tempos da existência (a amplitude do mundo vivente) e fazem com que a vida se perpetue. Através da fusão entre o corpo e o milho, flui conhecimento na forma de samai, uma partilha da criatividade que se reparte em muitas vidas e faz nascer, sob a existência de muitos olhos, a beleza nas formas e cores dos grãos e das mulheres - transformações da terra.

\section{Tatiana Lotierzo é mestre em Antropologia pela USP e doutoranda no PPGAS/ UnB.}

$41 C f$. Rosa Tisoy - Warmity: <http://rosatisoy.wixsite.com/rosy-tisoy-/portafolio >. Última consulta: 09/07/2018.

$42 C f$. Rosa Tisoy - Warmity: <http://rosatisoy.wixsite.com/rosy-tisoy-/portafolio>. Última consulta: 09/07/2018. 


\section{REFERÊNCIAS BIBLIOGRÁFICAS}

ALLEN, Catherine J. 1998. "When Utensils Revolt: Mind, Matter and Modes of Being in the Pre-Columbian Andes", RES, 33: 19-27. . 2002. The Hold Life Has: Coca and Cultural Identity in an Andean Community. Washington, DC: Smithsonian Institution Press. . 2015. “The Whole World Is Watching: New Perspectives on Andean Animism”, in L. BRAY, Tamara (ed.). The Archaeology of Wak'as: Explorations of the Sacred in the Pre-Columbian Andes. Colorado: University Press of Colorado. pp. 23-46.

ALMEIDA, Maria Inês de 2014. “Mira! Artes Visuais Contemporâneas dos Povos Indígenas”, Mundo Amazônico, 5: 185-188. e MATTOS, Beatriz (orgs.) 2013. Mira! Artes Visuais Contemporâneas dos Povos Indígenas. Catálogo de exposição. Belo Horizonte: Centro Cultural UFMG.

BAENA, Javier Espinel. 2004. “Dimensión Estética en el Diseño de los Chumbes Paeces y Guambianos. Qué es Diseño Hoy?’. Primer Encuentro Nacional de Investigación en Diseño, Universidad ICESI.

BARTHES, Roland. 1980. La Chambre Claire. Paris: Éditions de l’Étoile.

BELAUNDE, Luisa Elvira. 2006. "The Strength of Thoughts, the Stench of Blood: Amazonian Hematology and Gender". Tipiti: Journal of the Society for the Anthropology of Lowland South America, 4, Iss. 1, Article 7.

.2016. “Donos e Pinturas: Plantas e Figuração na Amazônia Peruana”. Mana, 22(3): 611-

640.

BENDAYÁN, Christian e VILLAR, Alfredo. 2013. Pintura Amazónica: El Milagro Verde. Lima: Forma e Imagen.

BRISTOL, Melvin. 1965. Sibundoy Ethnobotany. Tese (Doutorado em Biologia), Cambridge: Harvard University.

BURBANO MUÑOZ, Javier. 1999. "Etnobotanica en el Valle de Sibundoy: el Yagé y el Jajañ Forjadores del Saber y Tradición Indígenas" (Trabalho de Conclusão de Curso (Graduação em Engenharia Agrônoma), Palmira: Universidad Nacional de Colombia.

CALAMBÁS, Marisol. 2014. "No solo crear la memoria de nosotros como pueblos indígenas, sino enseñar a ver esa memoria”. Mundo Amazónico, 5: 189-195.

CAYÓN, Luis. 2013. Pienso, Luego Creo: la Teoría Makuna del Mundo. Bogotá: Instituto Colombiano de Antropología e Historia.

CHÁVEZ, Alvaro (org.). 1989. “Curanderismo (1ª parte)", in Memorias del V Congreso Nacional de Antropología, ICFES, Bogotá.

COELHO DE SOUZA, Marcela. 2002. O Traço e o Círculo: o Conceito de Parentesco entre os Jê e seus 
Antropólogos. Tese (doutorado em Antropologia): Universidade Federal do Rio de Janeiro.

.2004. Parentes de Sangue: Incesto, Substância e Relação no Pensamento Timbira. Mana $10(1): 25-60$.

CORPOAMAZONIA (ed.). 2010. Plan de Ordenación y Manejo de la Cuenca Alta del Río Putumayo. Mocoa: Corpoamazonía, WWF y Asociación Ampora.

CORTÉS GARZÓN, Liliana. 2015. Amazónicos: un Estudio de Pintores Amazónicos Actuales.

Tese (Doutorado em Arte e Musicologia), Universidad Autónoma de Barcelona, Espanha.

GARCÍA-BARRIGA, Hernando. 1974. Flora Medicinal de Colombia, Bogotá, Instituto de Ciencias Naturales, Universidad Nacional.

GIRALDO-TAFUR, Clara. 2000. "Medicina Tradicional de la Mujer Inga”, Revista de la Academia Colombiana de Ciencias, 24(90): 5-23.

DESCOLA, Philippe. 1986. La Nature Domestique. Symbolisme et Praxis dans L'Écologie des Achuar. Paris: Maison des Sciences de l'Homme.

EWART, Elizabeth. 2000. Living with Each Other: Selves and Alters Amongst the Panara of Central Brazil. Tese (doutorado em antropologia). London: London School of Economics.

.2003. "Lines and Circles: Images of Time in a Panará Village", Journal of the Royal Anthropological Institute, 9(2): 261-279.

. 2005. "Fazendo Pessoas e Fazendo Roças entre os Paraná do Brasil Central", Revista de Antropologia,48(1): 9-35.

HECHT, Susanna B. e POSEY, Darrell 1989. "Preliminary Results on Soil Management Techniques of the Kayapó Indians”. Advances in Economic Botany, 7: 174-188.

HEELAS, R. H. 1979. Social Organization of the Panará, a Gê Tribe of Central Brazil. Tese (doutorado em antropologia), Oxford: University of Oxford.

HUGH-JONES, Christine. 1979. From the Milk River: Spatial and Temporal Processes in Northwest Amazonia. Cambridge, Cambridge University Press.

GOW, Peter. 1989. “The Perverse Child: Desire in a Native Amazonian Economy”. Man, v. 24(4): $567-82$.

1991. Of Mixed Blood: Kinship and History In Peruvian Amazonia. Oxford: Clarendon.

. 1993. "Gringos and Wild Indians Images of History in Western Amazonian Cultures",

L'Homme, 126-128, abr.-dez, XXXIII (2-4): 327-347.

. 1997. O Parentesco como Consciência Humana: o Caso dos Piro. Mana 3(2): 39-65.

1999. Piro Designs: Painting as Meaningful Action in an Amazonian Lived World. The Journal of the Royal Anthropological Institute, 5(2): 229-246.

2001. An Amazonian Mith and its History. Oxford, Oxford University Press.

JACANAMIJOY CHASOY, Edgar e BASTIDAS JACANAMIJOY, Lizbeth. 2007. “Estudio sobre el Simbolismo en las Manifestaciones Artísticas Visuales de la Comunidad Indígena Inga de 
Santiago, Putumayo", Revista Educación y Pedagogía, vol. XIX, n. 49: 173-183.

JACANAMIJOY TISOY, Benjamín. 1998. El Chumbe Inga: una Forma Artística de Percepción del Mundo. Informe final - Beca de Creación VIII Convocatoria ColCultura. Bogotá [s.ed.].

2001. "Kaugsay Suyu Yuyay: Lugar, Vivir, Pensar. Conceptos de la Tradición Inga sobre el Territorio". In: Espacio y Territorios: Razón, Pasión e Imaginarios, Bogotá, Universidad Nacional de Colombia.

.2014. "El Arte de Contar y Pintar la Propia Historia”. Mundo Amazónico, [S.l.], v. 5(1):

211-219

2017. El Chumbe Inga, una Forma Artística de Percepción del Mundo. Edição Especial e ampliada, feita com recursos próprios.

JAMIOY JUAJIBIOY, Hugo. 2010. “Shinÿe Gunney, Brote de meu Sangue”, in Danzantes del Viento, Bogotá: Ministerio de Cultura.

KOWII, Manai. 2016. El Concepto Sumakruray: una Categoria que Permite Definir y Analizar las Funciones que Tiene el Arte para el Pueblo Kichwa-Otavalo. Dissertação (Mestrado em Estudos da Cultura), Quito: Universidad Andina Simón Bolívar.

LEACH, James. 2004. "Modes of Creativity", in Hirsch, E. and Strathern, M. (eds.), Transactions and Creations. Property Debates and the Stimulus of Melanesia. New York and Oxford: Berghahn Books.

LIMA, Tânia. 1996. “O Dois e seu Múltiplo: Reflexões sobre o Perspectivismo em uma Cosmologia Tupi", Mana, 2(2): 21-47.

MCCALLUM, Cecilia. 1989. Gender, Personhood and Social Organization Among the Cashinabua of Western Amazonia. Tese (doutorado em Antropologia), Londres: London School of Economics. MOJOMBOY CUATINDOY, Ángel. 2015. Simbología del Arte Inga - Chumbi (Fajas de 67 Passos) [online]. Disponível em: <http://makiwaruraskakuna.blogspot.com>, última consulta: 20/08/2018. MATTOS, Beatriz e BELAUNDE, Luisa Elvira. 2014. "Arte y Transformación: Experiencias e Imágenes de los Artistas de la Exposición ¡Mira!”. Mundo Amazónico, 5: 297-308.

MOYA, Ruth. 2013. "O Mundo Amazônico e o Mundo Andino em Dois Pintores Equatorianos na Exposição MIRA!”. In: ALMEIDA, Maria Inês de e MATTOS, Beatriz (orgs.). Mira! Artes Visuais Contemporâneas dos Povos Indígenas. Catálogo de exposição. Belo Horizonte: Centro Cultural UFMG. pp. 51-62.

OLIVEIRA, Joana Cabral de. 2012. Entre plantas e palavras. Modos de constituição de saberes entre os Wajäpi (AP). Tese (doutorado em Antropologia), São Paulo: Universidade de São Paulo. PINZÓN, Carlos e SUÁREZ, Rosa. 1979. “Locos y Embrujados”. Actas del Primer Congreso Mundial de Medicina Tradicional, Lima: Universidad de San Marcos.

POSEY, Darrell e PLENDERLEITH, K. 2002. Kayapó Ethnoecology and Culture. London: Routledge.

REEVE, M. E. 1988. “Cauchu Uras: Lowland Quichua Histories of the Amazon Rubber Boom”. In: 
J. Hill (Ed.), Rethinking History and Myth: Indigenous South American Perspectives on the Past. Urbana, IL: University of Illinois Press. pp. 19-34.

RIVAL, Laura. 1993. “The Growth of Family Trees: Understanding Huaorani Perceptions of the Forest", Man, 28(4): 635-652

. 2001. "Seed and Clone: the Symbolic and Social Significance of Bitter Manioc

Cultivation. In Beyond the Visible and the Material: the Amerindianization of Society in the Work of Peter Rivière. Oxford: Oxford University Press. pp. 57-80.

(ed.). 1998. The Social Life of Trees: Anthropological Perspectives on Tree Symbolism. Oxford:

Berg.

SANTOS-GRANERO, Fernando. 2011. “The Virtuous Manioc and the Horny Barbasco:

Sublime and Grotesque Modes of Transformation in the Origin of Yanesha Plant Life", Journal of Ethnobiology, 31(1): 44-71.

SEIJAS, Haydeé. 1969. The Medical System of the Sibundoy Indians of Colombia, Tese (Doutorado em Antropologia), Tulane: Tulane University.

SONTAG, Susan. 1977. On Photography. London: Penguin Books.

SORIA CASAVERDE, María Belén. 2013. "Uma Mira na MIRA! O Caráter Integrador e a Natureza Múltipla da Arte Indígena Contemporânea”. In: ALMEIDA, Maria Inês de e MATTOS, Beatriz (orgs.). 2013. Mira! Artes Visuais Contemporâneas dos Povos Indígenas. Catálogo de exposição. Belo Horizonte: Centro Cultural UFMG. pp. 9-17.

STRATHERN, Marilyn. 1995. The Relation. Issues in Complexity and Scale. Cambridge, Prickly Pear Press.

1992. Afternature. Cambridge: Cambridge University Press.

SUÁREZ GUAVA, Luis Alberto. 2003. El Tiempo entre los Inga de Bogotá. Una Experiencia Etnográfica. Facultad de Ciencias Humanas. Bogotá: Universidad Nacional.

SUAVITA, María Angelica e CAÑÓN G., Mario Alberto. 2005. Hacia una Propuesta de Enseñanza del Concepto de Medida en un Contexto Intercultural: Medicion del Espacio y El Tiempo, Projeto Curricular de Licenciatura em Matemática, Bogotá, Universidad Distrital Francisco José de Caldas.

TAUSSIG, Michael. 1987. Shamanism, Colonialism and the Wild Man: A Study in Terror and Healing. Chicago: Chicago University Press.

TISOY T., Benjamín (1983). Rigsisunchi Nucanchipa Ambi. Algunas Plantas Medicinales que Utilizan los Ingas del Valle de Sibundoy, Instituto Linguístico de Verano, serie Ciencias Naturales.

VIVEIROS DE CASTRO, Eduardo. 1996. “Os Pronomes Cosmológicos e o Perspectivismo Ameríndio". Mana, 2(2): 115-144.

WAGNER, Roy. 1977. “Analogic Kinship: a Dabiri Example”. American Ethnologist, 4: 623-642 . 1986. Symbols that Stand for Themselves. Chicago: The University of Chicago Press. 
Resumo: Este artigo propõe olhar para obras como Sara Indi (Milho de Sol) e Kanimi Alli Uñangapa (Sou Boa Semente), da artista inga Rosa Tisoy, buscando situá-las enquanto lugares onde o conhecimento se realiza como efeito da co-presença de seres que ali se encontram e lugares da criatividade, onde a vida se perpetua entre diferentes seres. Conhecer, como criar, é partilhar samai ("alento") e depende de um bonito pensar - suma yuyay -, aspecto importante do bem viver - suma kaugsay. Situado como lugar do conhecimento (um "lugar de vida e pensamento"), o trabalho de Rosa transita por fluxos criativos que percorrem as chagras (roças) e o chumbe (faixa tecida, com desenhos).

Palavras-chave: Rosa Tisoy; conhecimento; criatividade; chagra; chumbe

\section{EARTH FROM THE BODIES: NOTES ON CREATIVITY IN WORKS BY ROSA TISOY}

Abstract: This article proposes to look at works such as Sara Indi (Maize of Sun) e Kanimi Alli Uñangapa (I am a Good Seed), by inga artist Rosa Tisoy, seeking to situate them as places where knowledge is attained as an effect of the co-presence of beings and also places of creativity where life is perpetuated through different beings. To know, as well to create, is to share samai ("breath") and depends on beautiful thinking - suma yuyay -, an important dimension of buen vivir - suma kaugsay. As a place of knowledge (a "place of life and thinking"), Rosa's works move along creative flows that run through the chagras (gardens) and the chumbe (a woven belt that carries designs).

Keywords: Rosa Tisoy; knowledge; creativity; chagra; chumbe

SUBMETIDO: $03 / 09 / 2018$

APROVADO: $11 / 11 / 2018$ 
86 CAMPOS V.19 N.1 jan.jun.2018 